\title{
Alzheimer's disease - a neurospirochetosis. Analysis of the evidence following Koch's and Hill's criteria
}

Judith Miklossy

\begin{abstract}
It is established that chronic spirochetal infection can cause slowly progressive dementia, brain atrophy and amyloid deposition in late neurosyphilis. Recently it has been suggested that various types of spirochetes, in an analogous way to Treponema pallidum, could cause dementia and may be involved in the pathogenesis of Alzheimer's disease (AD). Here, we review all data available in the literature on the detection of spirochetes in AD and critically analyze the association and causal relationship between spirochetes and AD following established criteria of Koch and Hill. The results show a statistically significant association between spirochetes and $A D(P=1.5$ $\times 10^{-17}, \mathrm{OR}=20,95 \% \mathrm{Cl}=8-60, \mathrm{~N}=247$ ). When neutral techniques recognizing all types of spirochetes were used, or the highly prevalent periodontal pathogen Treponemas were analyzed, spirochetes were observed in the brain in more than $90 \%$ of AD cases. Borrelia burgdorferi was detected in the brain in $25.3 \%$ of AD cases analyzed and was 13 times more frequent in AD compared to controls. Periodontal pathogen Treponemas (T. pectinovorum, T. amylovorum, T. lecithinolyticum, T. maltophilum, T. medium, T. socranskii) and Borrelia burgdorferi were detected using species specific PCR and antibodies. Importantly, co-infection with several spirochetes occurs in AD. The pathological and biological hallmarks of AD were reproduced in vitro by exposure of mammalian cells to spirochetes. The analysis of reviewed data following Koch's and Hill's postulates shows a probable causal relationship between neurospirochetosis and AD. Persisting inflammation and amyloid deposition initiated and sustained by chronic spirochetal infection form together with the various hypotheses suggested to play a role in the pathogenesis of AD a comprehensive entity. As suggested by Hill, once the probability of a causal relationship is established prompt action is needed. Support and attention should be given to this field of AD research. Spirochetal infection occurs years or decades before the manifestation of dementia. As adequate antibiotic and anti-inflammatory therapies are available, as in syphilis, one might prevent and eradicate dementia.
\end{abstract}

Keywords: Alzheimer's disease, bacteria, Borrelia burgdorferi, dementia, infection, Lyme disease, periodontal pathogen, spirochetes, Treponema, syphilis

\section{Introduction}

The recognition that pathogens can produce slowly progressive chronic diseases has resulted in a new concept of infectious diseases. The pioneering work of Marshall and Warren has established that Helicobacter pylori (H. pylori) causes stomach ulcer [1]. Also the etiologic agent of Whipple's disease was revealed to be another bacterium, Tropheryma whippeli. Recent reports have documented that infectious agents also occur in atherosclerosis, cardio-

Correspondence: judithmiklossy@bluewin.ch

International Alzheimer Research Center, Prevention Alzheimer Foundation, Martigny-Combe, Switzerland and cerebrovascular disorders [2-10], diabetes mellitus [11-16], chronic lung [17-20] and inflammatory bowel diseases [1,21-25], and various neurological and neuropsychiatric disorders [26-31].

Nearly a century ago, Fischer, Alzheimer and their colleagues $[32,33]$ discussed the possibility that microorganisms may play a role in the formation of senile plaques. Historic data indicate that the clinical and pathological hallmarks of syphilitic dementia in the atrophic form of general paresis, caused by chronic spirochetal infection, are similar to those of AD. There is an increasing amount of data that indicates that spirochetes are involved in the 
pathogenesis of AD. This review presents historic and new data related to the involvement of spirochetes in AD. The goal was to critically analyze the association and causality between spirochetes and AD, based on the substantial amount of data available and on established criteria of Koch [34,35] and Hill [36]

\section{Pathological hallmarks and pathogenesis of Alzheimer disease}

$\mathrm{AD}$ is the most frequent cause of dementia and is characterized by a slowly progressive decline of cognition and memory. Alzheimer described the characteristic cortical senile plaques and neurofibrillary tangles in the brain of a 51-year-old woman who suffered from presenile dementia [37]. Recently, it was pointed out that the presenile form, with onset before age 65 , is identical to the most common form of senile dementia [38,39]. Therefore today the term AD is used for the designation of both presenile and senile cases.

The pathological hallmarks of AD are progressive brain atrophy and the accumulation of cortical senile plaques and neurofibrillary tangles. A fibrillary amyloid substance is deposited in senile plaques, formed by the aggregation of the $4.2-\mathrm{kD}$ amyloid beta peptide $(\mathrm{A} \beta) . \mathrm{A} \beta$ is derived by proteolytic cleavage from a transmembrane amyloid beta precursor protein $(\mathrm{A} \beta \mathrm{PP})$. Neurofibrillary tangles contain paired helical filaments (PHFs), and the major component of PHFs is the microtubule associated protein tau. Granulovacular degeneration is another characteristic alteration of neurons in AD.

The origins of $\mathrm{A} \beta$ deposition, neuronal tangle formation and granulovacuolar degeneration still remain unclear. Various hypotheses were proposed to explain the pathogenesis of $\mathrm{AD}[40,41]$. Mutations in A $\beta \mathrm{PP}$, presenilin 1 and presenilin 2 genes are implicated in inherited, early onset $A D$, but the frequency of familial cases is very low [42]. The epsilon 4 allele of apolipoprotein E (ApoE4) was revealed to be a risk factor for AD [43]. Polymorphisms of various genes, including numerous inflammatory genes [44] are associated with AD. The AlzGene database (http://www. alzgene.org) assembles and organizes the increasing number of AD related susceptibility genes [45]. It provides a comprehensive, unbiased and regularly updated data on genetic studies performed in $\mathrm{AD}$, including meta-analyses for various polymorphisms related to AD.

The relationship between the two major biological markers of AD $A \beta$ and hyperphosphorylated tau is not clear. That the soluble form of $A \beta$ and tau strongly interact [46] and that $\mathrm{A} \beta \mathrm{PP}$ is also expressed in neurofibrillary tangles [47] suggest that these apparently different pathologies are linked in AD.

The critical role of chronic inflammation in AD is now widely recognized. The important role of neuroinflammation and the importance of IL-1 signaling were first documented by McGeer, Rogers and Griffin [48-50]. Cellular and molecular components of the immune system reactions including the membrane attack complex (MAC, C5b-9) are associated with AD cortical lesions [51-54] and non-steroidal anti-inflammatory drugs (NSAIDs) reduce the risk of $55-80 \%$ for AD [55-57].

\section{The clinical and pathological hallmarks of AD are similar to those of the atrophic form of general paresis}

Historic observations show that the clinical and pathological hallmarks of $\mathrm{AD}$ are similar to those occurring in the atrophic form of general paresis [58,59]. Noguchi and Moore [60] by showing the presence of T. pallidum in the cerebral cortex of patients with general paresis provided the conclusive evidence that T. pallidum is responsible for slowly progressive dementia, cortical atrophy and local amyloidosis in the atrophic form of this chronic bacterial infection.

This form of general paresis is characterized by a diffuse, predominantly frontotemporal cortical atrophy. The characteristic pathological features comprise severe neuronal loss, reactive microgliosis and astrocytosis. Spirochetes form plaque-like cortical masses or colonies $[61,62]$. Pacheco e Silva $[61,62]$ by analyzing the brains of more than 60 patients with atrophic general paresis reported that the number of spirochetes and spirochetal plaques increased with the severity of cortical atrophy. The morphology and distribution of T. pallidum colonies are identical to those of senile plaques. Spirochetes are more numerous in the hippocampus and frontal cortex $[61,62]$ and accumulate without accompanying lymphoplasmocytic infiltrates. Another characteristic feature of the atrophic form of general paresis is the accumulation in the brain of "paralytic iron" [63]. Neurofibrillary tangles and amyloid deposition both occur in dementia paralytica [59,64-66]. Recent analysis of archival brain material of clinically and pathologically confirmed general paretic cases revealed that the local amyloid deposit in general paresis, as in $\mathrm{AD}$, consists of $\mathrm{A} \beta$ [67].

\section{Association of spirochetes and Alzheimer's disease}

That dementia associated with cortical atrophy and microgliosis also occurs in late stages of Lyme disease [68-73] caused by Borrelia burgdorferi (B. burgdorferi), suggested that various types of spirochetes in an analogous way to $T$. pallidum might cause dementia and brain pathology similar to AD.

Various Borrelia and Treponema species from the family Spirochaetaceae are responsible for diverse human diseases. From 36 known Borrelia species 12 cause Lyme disease or other borreliosis, which is transmitted by the 
bite of infected ticks. Relapsing fever is caused by nearly 20 species of Borrelia recurrentis and is transmitted by ticks and lice [74,75]. Near 60 diverse Treponema species were identified in subgingival pockets in human periodontal diseases [76,77]. These periodontal pathogen spirochetes comprise Treponema denticola, Treponema socranskii, Treponema pectinovorum, Treponema amylovorum, Treponema lecithinolyticum, Treponema maltophilum and Treponema medium. Treponema vincentii causes necrotizing fusospirochetal disease called Vincent angina. Many other Treponema species are present in the human genital mucosa. From the family Brachyspiraceae, two species of the genus Brachyspira (B.), i.e. B. aalborgi and B. (Serpulina) pilosicoli are responsible for human intestinal spirochetosis [78,79]. Spirochetes of the genus Leptospira, family Leptospiraceae, cause human leptospirosis.

\section{Detection of all types of spirochetes}

To verify the hypothesis that several types of spirochetes may be involved in AD, $147 \mathrm{AD}$ cases and 37 controls were analyzed using neutral techniques, which recognize all types of spirochetes.

In an initial study, helically shaped microorganisms were observed in $14 \mathrm{AD}$ cases in the cerebrospinal fluid (CSF), blood and cerebral cortex [70]. They were isolated from the cerebral cortex, and cultivated from the blood in a modified Noguchi medium, which enables the cultivation of anaerobic spirochetes. They were absent in agematched controls, which were without any AD-type cortical changes [70]. In three AD cases, spirochetes were also cultivated from the cerebral cortex in a synthetic Barbour-Stoenner-Kelly II (BSK II) medium [70]. Further scanning electron microscopy and atomic force microscopy analyses defined that these helically shaped microorganisms possess endoflagella and taxonomically belong to the order Spirochaetales [80]. Spirochetes were detected in the brains of 8 AD patients derived from another laboratory and in the blood of 5 living patients with AD-type dementia [81]. In addition to dark field, atomic force, electron and immune-electron microscopy analyses, immunohistochemical detection of spirochetes was also performed using spirochete and bacterial peptidoglycan (PGN) specific antibodies, and by using the nonspecific DNA marker 4',6-Diamidine-2'-phenylindole dihydrochloride (DAPI) and species-specific DNA as revealed by in situ hybridization (ISH) [70,80-86]. PGN is the building block of the cell wall of virtually all Eubacteria, including spirochetes, however, Mycoplasma and Chlamydia, which lack bacterial cell wall, do not show detectable PGN $[87,88]$. The morphology of helically shaped microorganism detected by spirochete or PGN specific antibodies is identical [compare Fig. seven G and
$\mathrm{H}$ of reference 89]. PGN-immunoreactive helically shaped spirochetes were detected in the brains in 32 definite $\mathrm{AD}$ cases and in 12 cases with mild or moderate AD-type cortical changes $[87,88]$. Spirochetes were observed in senile plaques, neurofibrillary tangles, curly fibers and in the wall of cortical or leptomeningeal arteries exhibiting amyloid deposits [70,80-82]. Spirochete and PGN specific antigens were co-localized with A $\beta[83,85]$. Control brains without AD-type cortical changes were negative [70,83-85]. These observations have suggested that various types of spirochetes of the order Spirochaetales, might cause dementia and contribute to the pathogenesis of AD.

McLaughlin et al., [90] did not find spirochetes by dark field and electron microscopy in the brains of 7 AD cases tested. They observed spirochetes in the blood in one of 22 clinically diagnosed AD patients (Table 1). The spirochete illustrated by the authors corresponds to a regularly spiral vegetative form. It is not clear, whether the atypical, pleomorphic spirochete forms, which are common in blood and in infected tissues [89,91-93] were considered or not in this study. The authors have suggested that the spirochete observed could correspond to oral Treponema.

In all these studies, which detected spirochetes using neutral techniques, 680 brain and blood samples were analyzed. In AD, more than $91.1 \%$ (451/495) of the samples were positive, while the 185 control samples were all negative.

\section{Periodontal pathogen spirochetes}

Oral anaerobic Treponema (T) spirochetes are predominant periodontal pathogens, which are highly prevalent in the population. Several of them revealed to be invasive in vivo and in vitro $[94,95]$. Six different periodontal pathogen spirochetes, specifically, T. denticola, $T$. pectinovorum, T. vincenti, T. amylovorum, T. maltophilum, T. medium and T. socranskii were detected in the brains of AD patients using species specific PCR. At least one oral Treponema species was detected in 14 of $16 \mathrm{AD}$ cases, and in 4 of 18 controls [96]. Species-specific antigens of T. pectinovorum and $T$. socranskii were observed in $15 \mathrm{AD}$ and in 7 controls $(\mathrm{P}<0.001)$. Six different Treponema species were detected in the brain in one $\mathrm{AD}$ patient, five species in four, four or three species each in one, and one species in seven AD cases. Of the four controls with Treponema spirochetes, one had two Treponema species and three one species each. The number of diverse Treponema species was significantly higher in the brains of AD patients compared to controls [96]. Treponema antigens were detected both in the hippocampus and frontal cortex. These important results, as proposed earlier [70,80-82], indicate that periodontal pathogen spirochetes in an 
Table 1 Detection of spirochetes in Alzheimer disease

\begin{tabular}{|c|c|c|c|c|c|c|c|}
\hline Authors & $\mathrm{N}$ & Mat & Meth & $A D$ & CTRL & Cult & Serol \\
\hline \multicolumn{8}{|l|}{ Detection of all types of spirochetes } \\
\hline Miklossy, 1993 \& Miklossy et al., 1994 [70,80] & 27 & Brain, BI, CSF & $\mathrm{DF}, \mathrm{HC}, \mathrm{HHC}, \mathrm{EM}, \mathrm{AFM}$ & $14 / 14$ & $0 / 13^{* *}$ & 14/14 (B| 4/5) & $\mathrm{Nd}$ \\
\hline Miklossy, 1994 [81] & $\begin{array}{c}12 \\
5 \\
\end{array}$ & $\begin{array}{c}\text { Brain } \\
\mathrm{Bl}\end{array}$ & $\begin{array}{l}\text { DF } \\
\text { DF }\end{array}$ & $\begin{array}{l}8 / 8 \\
5 / 5 \\
\end{array}$ & $0 / 4^{* *}$ & $\begin{array}{l}8 / 8 \\
\mathrm{Nd}\end{array}$ & $\begin{array}{l}\mathrm{Nd} \\
\mathrm{Nd}\end{array}$ \\
\hline Miklossy et al., 1995 [82] & $\begin{array}{c}24 \\
10^{* * *}\end{array}$ & Brain & DNA-DAPI & $\begin{array}{c}20 / 20 \\
10 / 10^{* * *}\end{array}$ & $0 / 4^{* *}$ & $\mathrm{Nd}$ & $\mathrm{Nd}$ \\
\hline Miklossy et al., 1996, Miklossy, 1998 [83,84] & 54 & Brain & $\mathrm{HC}$ & $\begin{array}{l}32 / 32 \\
12 / 12^{*}\end{array}$ & $0 / 10^{* *}$ & $\begin{array}{l}\mathrm{Nd} \\
\mathrm{Nd}\end{array}$ & $\begin{array}{l}\mathrm{Nd} \\
\mathrm{Nd}\end{array}$ \\
\hline McLaughlin et al., 1999 [90] & $\begin{array}{c}7 \\
28\end{array}$ & $\begin{array}{c}\text { Brain } \\
\text { Bl }\end{array}$ & DF, EM & $\begin{array}{c}0 / 7 \\
1 / 22\end{array}$ & $0 / 6$ & $\begin{array}{l}\mathrm{Nd} \\
\mathrm{Nd}\end{array}$ & $\begin{array}{l}\mathrm{Nd} \\
\mathrm{Nd}\end{array}$ \\
\hline
\end{tabular}

Total: Various types of spirochetes detected using neutral techniques

Brain: $A D N=102, A D 64 / 71, C T R L$ 0/31", P $=4.8 \times 10^{-18}, \mathrm{OR}^{\prime \prime}=274,95 \% \mathrm{Cl}=32-11345$

Brain: $A D$, mild $A D N=114, A D 76 / 83, C T R L 0 / 31^{\prime \prime}, P=1 \times 10^{-19}, O^{\prime \prime}=325,95 \% \mathrm{Cl}=38-13440$

Brain, $\mathrm{BI}, \mathrm{CSF}$ : AD, mild AD N = 147, AD 82/110, CTRL 0/37", P = $1.1 \times 10^{-15}, \mathrm{OR}^{\prime \prime}=105,95 \% \mathrm{Cl}=13-4329$

\begin{tabular}{|c|c|c|c|c|c|c|c|}
\hline \multicolumn{8}{|l|}{ Periodontal pathogen spirochetes } \\
\hline Riviere et al, 2002 [96] & 34 & Brain, & $P C R, I H C$ & $15 / 16$ & $6 / 18$ & $\mathrm{Nd}$ & $\mathrm{Nd}$ \\
\hline \multicolumn{8}{|c|}{ Total: Periodontal pathogen spirochetes detected in the brain } \\
\hline \multicolumn{8}{|c|}{ Brain: $A D, N=34, A D 15 / 16, C T R L 6 / 18, P=3.6 \times 10^{-4}, O R=30,95 \% C l=2.8-1364$} \\
\hline \multicolumn{8}{|l|}{ Borrelia burgdorferi } \\
\hline MacDonald \& Miranda1987 [98] & 2 & Brain & $\mathrm{IHC}$ & $1 / 1$ & $0 / 1$ & + & $\mathrm{Nd}$ \\
\hline MacDonald, 1988 [99] & 1 & Brain & $\mathrm{DF}, \mathrm{IHC}$ & $1 / 1$ & & + & $\mathrm{Nd}$ \\
\hline Pappolla et al., 1989 [103] & 10 & Brain & $\mathrm{EM}, \mathrm{IHC}, \mathrm{Wbl}$ & $0 / 6$ & $0 / 4$ & - & $\mathrm{Nd}$ \\
\hline Miklossy, 1993 and Miklossy et al., 2004 [70,85] & $27^{* * *}$ & Brain $\mathrm{Bl}, \mathrm{CSF}$ & Cult, IHC, EM, ISH, 16SrRNA & $3 / 14^{* * *}$ & $0 / 13^{* * *}$ & $3 / 14$ & $2 / 14$ \\
\hline Miklossy, 1993 [70] & 1 & Brain & $\mathrm{IHC}$ & $1 / 1$ & & $\mathrm{Nd}$ & $1 / 1$ \\
\hline Gutacker et al., 1998 [104] & 10 & Brain & PCR & $0 / 10$ & & - & $\mathrm{Nd}$ \\
\hline Marques et al., 2000 [105] & 30 & Brain & PCR & $0 / 15$ & $0 / 15$ & $\mathrm{Nd}$ & $\mathrm{Nd}$ \\
\hline Riviere et al., 2002 [96] & $34^{* * *}$ & Brain & $P C R$, seq & $5 / 16^{* * *}$ & $1 / 18^{* * *}$ & $\mathrm{Nd}$ & $\mathrm{Nd}$ \\
\hline Meer-Scherrer et al., 2006 [100] & 1 & Brain & PCR & $1 / 1$ & & $\mathrm{Nd}$ & $1 / 1$ \\
\hline MacDonald, $2006[101,102]$ & 11 & Brain & $\mathrm{PCR}, \mathrm{IHC}$ & $7 / 10$ & $0 / 1$ & $\mathrm{Nd}$ & $1 / 1$ \\
\hline
\end{tabular}

Total: All studies detecting Borrelia burgdorferi

Brain: AD N = 127, AD 19/75, CTRL 1/52, P $=2.9 \times 10^{-4}, \mathrm{OR}=17,95 \% \mathrm{Cl}=2-732$

Total: All studies detecting spirochetes

Brain: $A D N=202, A D 90 / 131, C T R L 6 / 71, P=1.7 \times 10^{-17}, \mathrm{OR}=23,95 \% \mathrm{Cl}=9-71$

Brain: $A D$, mild $A D N=214, A D 102 / 143, C T R L 6 / 71, P=1.5 \times 10^{-19}, O R=26,95 \% \mathrm{Cl}=10-80$

Brain, $\mathrm{BI}, \mathrm{CSF}: \mathrm{AD}$, mild AD N $=247, \mathrm{AD} 108 / 170, \mathrm{CTRL} 6 / 77, \mathrm{P}=1.5 \times 10^{-17}, \mathrm{OR}=20,95 \% \mathrm{Cl}=8-60$

Data reviewed in the literature with respect to the detection of all types of spirochetes using neutral techniques and the specific detection of periodontal pathogen Treponemas and Borrelia burgdorferi. Results of the statistical analysis are given for each group and for all studies together. $\mathrm{N}=$ total number of cases investigated, $\mathrm{AD}=$ Alzheimer disease, $C T R L=$ control, Mat = material, Meth = methods, Cult = culture, Serol = serology, $A D=$ Number of $A D$ cases positive for spirochetes $/$ number of $A D$ cases analyzed, $\mathrm{CTRL}=$ Number of control cases positive for spirochetes/number of control cases analyzed, $\mathrm{BI}=$ blood, $\mathrm{CSF}=$ cerebrospinal fluid, $\mathrm{EM}=$ electron microscopy, AFM = atomic force microscopy, DF = dark field microscopy, HC = histochemistry (Warthin and Starry, Bosma-Steiner silver stain for spirochetes), IHC = immunohistochemistry, $\mathrm{ISH}=$ in situ hybridization, $\mathrm{PCR}=$ polymerase chain reaction, $\mathrm{Bb}=$ Borrelia burgdorferi, $\mathrm{Wbl}=$ Western blot, $\mathrm{P}=$ exact value of the significance calculated by the Fischer test, $\mathrm{OR}=$ Odds Ratio, $\mathrm{Cl}=95 \%$ confidence interval,$+=$ positive, $-=$ negative, $\mathrm{Nd}=$ not done, seq $=$ sequence analysis, ${ }^{*}=$ cases with mild or moderate AD-type cortical changes, ${ }^{* *}=$ controls without any AD-type changes, ${ }^{* * *}=$ cases from previous studies, which were subtracted when the total number of cases of studies were considered, " = the number of 0 positive control was changed to 1 in order to calculate the exact OR and $\mathrm{Cl}$ values.

identical way to T. pallidum have the ability to invade the brain, persist in the brain and cause dementia. They also indicate that co-infection by several spirochetes occurs in AD. These findings are in agreement with recent observations showing an association between periodontal diseases and $\mathrm{AD}$ [97].

\section{Borrelia burgdorferi}

B. burgdorferi was first cultivated from the brain in two AD patients by MacDoald and Miranda [98] and MacDonald [99] and in 3 definite AD cases by Miklossy [85] (Table 1). Extensive characterization of the cultivated spirochetes confirmed, that the morphological, histochemical 
and immunohistochemical properties of these spirochetes are identical to those of $B$. burgdorferi $[85,86]$. Electron microscopic analysis demonstrated that they possess 10-15 endoflagella representative of B. burgdorferi species. $16 \mathrm{~S}$ rRNA gene sequence analysis definitely identified the cultivated spirochetes as Borrelia species sensu stricto (s. s.) [85]. In two of these AD cases post mortem serological analyses of blood and cerebrospinal fluid (CSF) have revealed a positive serology for $B$. burgdorferi fulfilling the diagnostic criteria of the Center for Disease Control (CDC). B. burgdorferi specific antigens and genes were detected in the brains of these three AD patients where $B$. burgdorferi was cultivated. Neurofibrillary tangles were also immunoreactive with specific anti-B. burgdorferi antibodies and Borrelia antigens were co-localized with $A \beta$. Using in situ hybridization (ISH) B. burgdorferi specific OspA and flagellin genes were detected in senile plaques and in a number of neurofibrillary tangles [85]. Importantly, the cortical distribution of spirochete masses or colonies was identical to that of senile plaques. The pathological changes observed in the brain were similar to those occurring in the atrophic form of general paresis and in AD.

B. burgdorferi specific antigens were observed in the brain in an additional AD patient with concurrent Lyme neuroborreliosis [70]. Using species-specific PCR, B. burgdorferi DNA was detected in the brains in 5 of $16 \mathrm{AD}$ patients and in one of 18 controls [96]. In these 6 positive cases (5 AD and 1 control) B. burgdorferi co-infected with oral Treponema spirochetes. $B$. burgdorferi specific DNA was detected by PCR in the brain of an additional patient with concurrent $\mathrm{AD}$ and Lyme neuroborreliosis [100] and in the hippocampus in 7 of 10 pathologically confirmed definite AD cases using PCR or ISH $[101,102]$ (Table 1).

Pappolla et al., [103] who failed to detect B. burgdorferi in the brains of $6 \mathrm{AD}$ cases and 4 controls concluded that the possibility of a different spirochete in $\mathrm{AD}$ not detectable by their methods could not be excluded, considering the possibility that several types of spirochetes may be involved in AD. Indeed, the goal of initial studies was not to show the involvement of B. burgdorferi alone in AD but that of the involvement of various types of spirochetes of the order Spirochaetales, including B. burgdorferi, oral, intestinal and other, yet uncharacterized spirochetes $[70,80-84,86]$. The title of the initial report, "Alzheimer's disease - A spirochetosis?", clearly indicates this goal [70].

In the two other studies where $B$ burgdorferi was not detected in the brain, evidence is lacking whether the analyzed $\mathrm{AD}$ patients suffered from Lyme neuroborrelisosis [104,105] (Table 2). We cannot expect to detect $B$. burgdorferi in the brains of AD patients who have no Lyme neuroborreliosis. An example is the analysis of the involvement of T. pallidum in syphilitic dementia. If we would like to demonstrate the involvement of T. pallidum in dementia in a population without syphilis, we cannot succeed, despite the established fact that this spirochete can cause dementia. In order to study the involvement of $B$. burgdorferi in $\mathrm{AD}$, the analysis of AD patients suffering from Lyme disease is necessary.

Similarly, due to the low incidence of Lyme dementia compared to $\mathrm{AD}$, the analysis of the seroprevalence of B. burgdorferi alone may be disappointing $[104,106]$ (Table 2). In such studies it is difficult to prove the

Table 2 Serological analysis of Borrelia burgdorferi in Alzheimer disease

\begin{tabular}{|c|c|c|c|c|c|c|}
\hline Authors & $\mathrm{N}$ & Mat & Meth & $A D$ & CTRL & Cult \\
\hline Pappolla et al., 1989 [103] & 47 & CSF & ELISA & $2 / 16$ & $2 / 31$ & $\mathrm{Nd}$ \\
\hline Gutacker et al., 1998 [104] & 27 & $\mathrm{Bl}$, & ELISA, Wbl & $1 / 27$ & & $\mathrm{Nd}$ \\
\hline Miklossy, 1993 and Miklossy et al., 2004 [70,85] & 7 & $\mathrm{Bl}, \mathrm{CSF}$ & ELISA, IFAT, WbI & $2 / 4$ & $0 / 3$ & + \\
\hline Miklossy, 1993 [70] & 1 & $\mathrm{Bl}$ & ELISA & $1 / 1$ & & $\mathrm{Nd}$ \\
\hline Meer-Scherrer et al., 2006[100] & 1 & $\mathrm{Bl}$ & ELISA, WbI & $1 / 1$ & & $\mathrm{Nd}$ \\
\hline MacDonald, $2006[101,102]$ & 1 & $\mathrm{~B} \mid$ & ELISA, WbI & $1 / 1$ & & $\mathrm{Nd}$ \\
\hline Galbussera et al., 2008 [106] & 98 & $\mathrm{Bl}$ & ELFA & $1(+/-) / 50$ & $0 / 48$ & $\mathrm{Nd}$ \\
\hline
\end{tabular}

Total: Borrelia burgdorferi serology

Blood: $\mathrm{N}=135, \mathrm{AD}: 7 / 84$ (8.3\%), CTRL: 0/51, (0\%) “P $=0.2581, \mathrm{OR}=4.5, \mathrm{Cl}=0.5-208$

Blood \& CSFN = 182, AD: 9/100 (9\%), CTRL: $2 / 82$ (2.43\%), $\mathrm{P}=0.1147, \mathrm{OR}=3.95, \mathrm{Cl}=0.78-38$

Data reviewed in the literature on the serological detection of $B$. burgdorferi specific antibodies in Alzheimer's disease. There is no statistically significant difference between $A D$ and controls. The frequency of positive $B$. burgdorferi serology is more than eight times higher in the blood (7/84 versus $0 / 51$ ) and almost four times higher when taken together blood and CSF (4.3\% versus $2.5 \%)$ in AD compared to controls. The Odds ratio values (4.5 and 3.95$)$ indicate that positive B. burgdorferi serology represents a risk for $A D$. $N=$ total number of cases investigated, $A D=$ Alzheimer disease, $C T R L=$ control, Mat $=$ material, Meth $=$ methods, Cult $=$ culture, $A D=$ Number of $A D$ cases with positive serology to $B$. burgdorferi /number of $A D$ cases analyzed, $C T R L=$ Number of $A D$ cases with positive serology to $B$. burgdorferi /number of control cases analyzed, $\mathrm{BI}=$ blood, CSF = cerebrospinal fluid, WbI = Western blot, IFAT = Indirect Immunofluorescent Antibody Test, ELISA = Enzyme-Linked Immunoabsorbent Assay, ELFA = Enzyme-Linked Fluorescence Assay, $\mathrm{P}=$ exact value of the significance calculated by the Fischer test, $\mathrm{OR}=$ Odds Ratio, $\mathrm{Cl}=95 \%$ confidence interval, $+=$ positive, $\mathrm{Nd}=$ not done, " = the number of 0 positive control was changed to 1 in order to calculate the exact $\mathrm{OR}$ and $\mathrm{Cl}$ values. 
involvement of B. burgdorferi in $\mathrm{AD}$ and we cannot exclude the involvement of other spirochetes. As one may expect, there is no statistically significant difference between the positive blood and/or CSF serology between such $\mathrm{AD}$ and control populations $(\mathrm{P}=0.1147)$. However, it is noteworthy, that the frequency of positive blood serology for B. burgdorferi is about 8 times higher in AD and considering both blood and CSF serology about 4 times higher (9\%) compared to controls $(2.43 \%)$. The high OR values (4.5 and 3.95, respectively) are also indicative of a higher risk of positive B. burgdorferi serology in AD. This is in harmony with the findings that in a statistically significant proportion of the AD population analyzed (25.3\%) B. burgdorferi was detected in the brain. It is also noticeable that in all those studies, which show the involvement of $B$. burgdorferi in $\mathrm{AD}$, the patients had a positive serology for $B$. burgdorferi and/or this spirochete was cultivated from the brain in BSK medium $[70,85,98,99]$ or species-specific DNA was detected in the brain [96] indicating that these AD patients suffered from Lyme neuroborreliosis. Importantly, the majority of AD patients analyzed in these studies came from endemic areas of Lyme disease $[70,85,98,99,101,102]$. To consider, that the results may also vary depending whether the patients analyzed were living in endemic areas of Lyme disease is also important, when analyzing B. burgdorferi.

In future studies, to consider that several types of spirochetes can co-infect in $\mathrm{AD}$ [96] and that spirochetes frequently exhibit pleomorphism in host tissues [89] is also essential. In view of an infectious origin of AD the use of appropriate healthy control population without AD-type cortical changes and without other neuro-psychiatric disorders is also essential.

Taken together, these observations derived from various laboratories show that several types of spirochetes can infect the brain in AD and co-infection with several types of spirochetes occurs. As expected, the frequency of periodontal pathogen spirochetes is higher compared to that of B. burgdorferi, which is present in less then one third of the AD cases analyzed. The significantly higher frequency of B. burgdorferi in the brain of AD patients, the high risk factor and the results of the multifaceted analysis in three $\mathrm{AD}$ patients with concurrent Lyme neuroborreliosis, where B. burgdorferi was cultivated from the brain and species specific antigens and DNA were present in the cerebral cortex show that $B$. burgdorferi is involved in the pathogenesis of a subset of AD cases [85].

\section{Analysis of the association of spirochetes and AD}

Based on the substantial data available in the literature, contingency tables were used to analyze the strength of the association between spirochetes and AD. Fisher test was used to assess whether the difference between the occurrence of spirochetes in AD and controls is statistically significant. Odds ratio (OR) and 95\% confidence interval (CI) values were also computed. If in the control group the number of positive cases was 0 in order to calculate OR and 95\% CI 1 positive control case was added (Table 1).

In those studies where all types of spirochetes were detected employing neutral techniques (Table 1, Figure 1), spirochetes were observed in the brain in $90.1 \%(64 / 71)$ of $\mathrm{AD}$ cases and were absent in controls without any ADtype changes (Table 1$)$. The difference was significant $(\mathrm{P}=$ 4.8. $\times 10^{-18}$; OR $=274,95 \% \mathrm{CI}=32-11345, \mathrm{~N}=102$ ). When cases with mild or moderate AD-type changes were also included as preclinical stages of AD, $91.5 \%$ of the cases $(76 / 83)$ were positive $\left(\mathrm{P}=1 \times 10^{-19}\right.$; $\mathrm{OR}=325,95 \%$ $\mathrm{CI}=38-13440, \mathrm{~N}=114)$. The difference remains significant when those cases were also included where spirochetes were analyzed in the blood $\left(\mathrm{P}=1.1 \times 10^{-15}\right.$, OR = $105,95 \% \mathrm{CI}=13-4329$ ).

The association between periodontal pathogen spirochetes and AD was statistically significant as well (Table 1 , Figure 2). They were detected in the brain in $93.7 \%$ of $\mathrm{AD}$

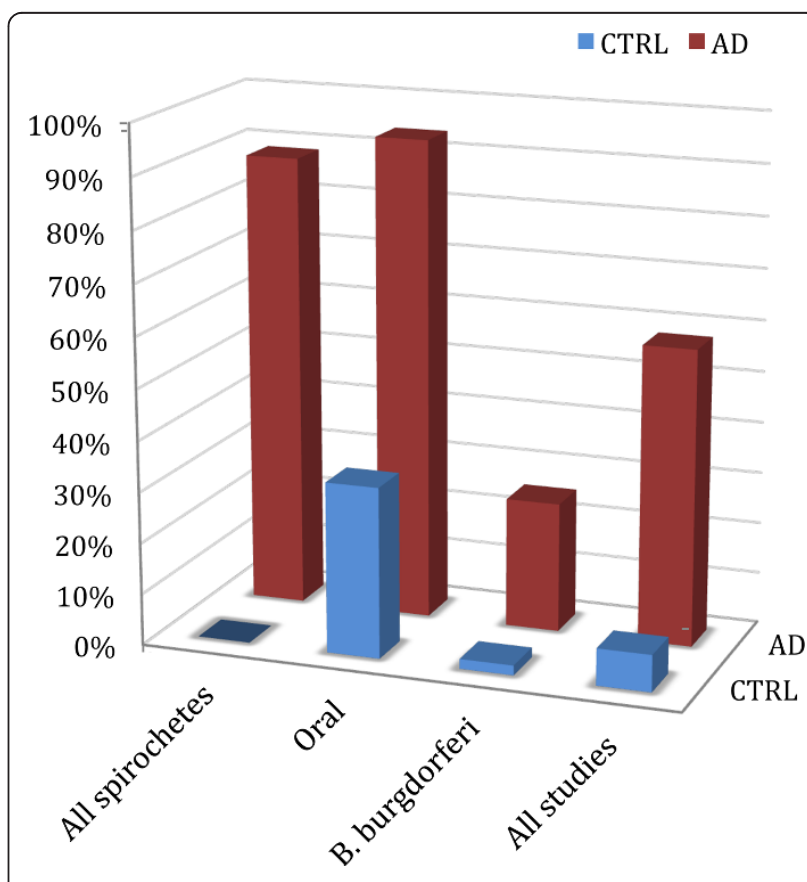

Figure 1 Association of spirochetes with Alzheimer's disease. The frequency of spirochetes is significantly higher in the brains of Alzheimer patients compared to controls. The statistical analysis is based on the cumulative data of the literature entered in Table 1. The association is statistically significant in the four groups analyzed: in the group where all types of spirochetes were detected using neutral techniques (All spirochetes), in the group of oral periodontal pathogen spirochetes (Oral spirochetes), in the group where Borrelia burgdorferi was detected alone (B. burgdorferi) and in the group where all studies were considered (All studies). 


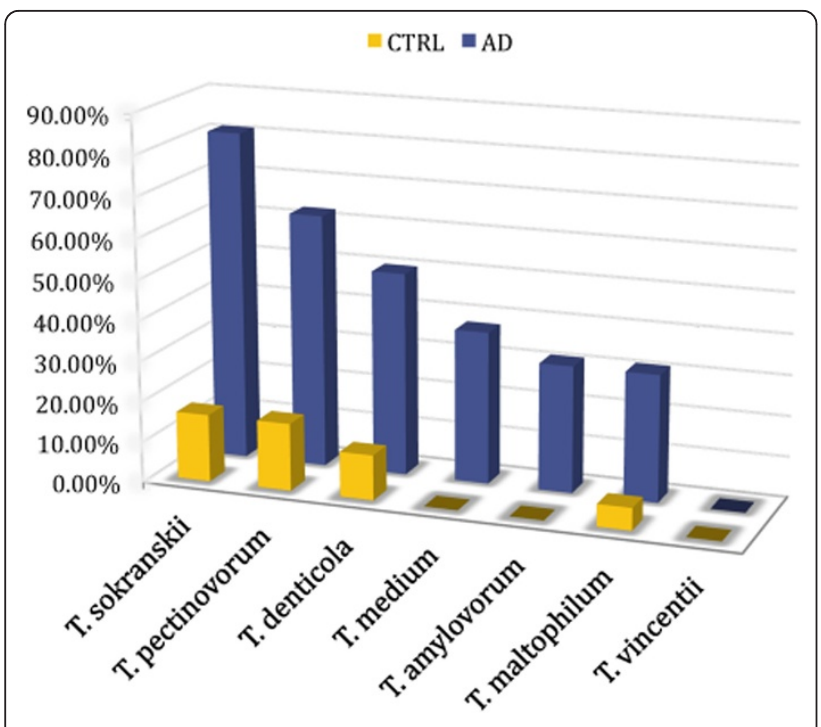

Figure 2 Association of oral invasive periodontal Treponema (T.) spirochetes with Alzheimer's disease. Using species specific PCR and antibodies six of seven periodontal pathogen spirochetes analyzed were detected in the brains of AD patients [96], (Table 1). The association of oral Treponemas with Alzheimer's disease is statistically significant [96], (Table 1).

and in $33.3 \%$ of control cases $\left(\mathrm{P}=3.6 \times 10^{-4}\right.$; $\mathrm{OR}=30$; 95\% CI $=2.8-1364 ; \mathrm{N}=34)$.

B. burgdorferi (Table 1, Figure 1) was observed 13 times more frequently in the brain in $\mathrm{AD}(19 / 75,25.3 \%)$ compared to controls $(1 / 52,1.9 \%)\left(\mathrm{P}=2.9 \times 10^{-4}\right.$, OR = 17; 95\% CI: 2 - 732; $\mathrm{N}=127$ ). The low prevalence of Lyme disease compared to AD is well reflected by the lower frequency (25.3\%) of B. burgdorferi compared to the higher, more than $90 \%$ frequency of all types of spirochetes detected with neutral techniques or the highly prevalent periodontal pathogen spirochetes.

When considering all studies (Table 1, Figure 1) detecting all types of spirochetes and their specific species, their frequency was 8 times higher in the brain in AD (90/ $131=68.7 \%)$ compared to controls $(6 / 71=8.45 \%)$. The difference is statistically significant $\left(\mathrm{P}=1.7 \times 10^{-17}\right.$; $\mathrm{OR}=$ 23; $95 \% \mathrm{CI}=9-71, \mathrm{~N}=202$ ). The association remains strongly significant when the 12 cases with mild AD-type changes $\left(\mathrm{P}=1.5 \times 10^{-19}, \mathrm{OR}=26,95 \% \mathrm{CI}=10-80, \mathrm{~N}=\right.$ $214)$ or those cases where spirochetes were analyzed in the blood were also included $\left(\mathrm{P}=1.5 \times 10^{-17}\right.$, OR $=20$, $95 \% \mathrm{CI}=8-60, \mathrm{~N}=247$ ). If considering errors, which may arise from those studies where the detection of spirochetes was restricted to B. burgdorferi alone, without considering other spirochetes, the percentage of spirochetes in AD would be even higher than $68.7 \%$. This is supported by the high percentage of spirochetes in studies where all types of spirochetes were detected using neutral techniques $(90.1 \%)$ or where the highly prevalent periodontal pathogen spirochetes were analyzed (93.7\%).
Taken together, these results show a strong, statistically significant association between spirochetes and AD and show that these microorganisms represent a strong risk for $\mathrm{AD}$.

\section{Further experimental evidence for a causal relationship between spirochetes and AD}

Additional studies have brought further evidence in support of a probable causal relationship between spirochetes and AD. For these experimental studies B. burgdorferi was employed, as this spirochete can be cultivated in synthetic medium and maintained in pure culture.

When primary neuronal and glial cells and brain cell aggregates were exposed to $B$. burgdorferi sensu stricto spirochetes (B. burgdorferi strain B31 and strains ADB1 and ADB2 cultivated from the brains of AD patients), Thioflavin S positive and A $\beta$-immunoreactive "plaques" as well as tangle- and granular lesions similar to granulovacuolar degeneration were induced [107]. Spirochete induced $A \beta$ accumulation was identified by Western blot and the $\beta$-pleated sheet conformation of the amyloid in spirochete-induced plaques was detected in situ using Synchrotron InfraRed MicroSpectroscopy (SIRMS). Borrelia induced tau phosphorylation and increased $A \beta P P$ levels represented additional experimental evidences that spirochetes are able to induce an AD-type host reaction [107].

Both, reference Borrelia spirochetes (B31) and those cultivated from the brains of AD patients (ADB1 and ADB2 strains) invaded neurons and glial cells and induced nuclear fragmentation, indicating that these spirochetes are invasive $[89,107]$. They were located extra- and intracellularly. Their intracellular location indicates that they can be protected from destruction by the host immune reactions $[70,89,107]$. These results show that in an analogous way to T. pallidum they can persist in the brain and cause dementia, cortical atrophy and the pathological hallmarks of AD.

It is noteworthy that spirochetes frequently co-infect with other bacteria and viruses. Co-infection of T. pallidum with other bacteria, various Herpes viruses and Candida albicans was frequently observed in syphilis [91]. In Lyme disease, in addition to various co-infections transmitted by tick-bite (e.g. bartonellosis, ricketttsiosis, babesiosis etc.) B. burgdorferi frequently co-infects with other pathogens, which are independent of the tick-bite, e.g. Clamydophyla pneumoniae (C. pneumonia) [108] and Herpes viruses [108-111]. Co-infection of spirochetes with C. pneumonia also occurs in a Lyme-like tick-borne disease in Brazil [112]. Intriguingly, C. pneumoniae $[113,114]$ and Herpes simplex type 1 (HSV-1) $[115,116]$ were also detected in the brain in $\mathrm{AD}$, suggesting that similarly to Lyme disease and syphilis, concurrent infection with several pathogens may frequently occur in $\mathrm{AD}$ as well. 
C. pneumoniae, H. pylori, periodontal pathogens, including $T$. denticola and Herpes viruses are also linked to atherosclerosis $[2,3,7]$, cardiovascular disorders $[4,6,117]$ and diabetes mellitus $[16,118,119]$, which indicate that these infectious agents, via hematogenous dissemination, may reach and infect various organs distant from the site of the primary infection. In agreement with this view, epidemiological studies revealed a close association between periodontal diseases and these chronic disorders [120]. It is noteworthy that AD is not only associated with these chronic inflammatory disorders but with chronic periodontal disorders as well [121].

\section{Mechanisms involved in spirochete-host interaction and their similarities to AD}

The strong neurotropism of spirochetes is well known. Spirochetes can invade the brain and generate latent, persistent infection $[29,63,65]$. In addition to hematogenous dissemination, they can spread via the lymphatics and along nerve fiber tracts $[63,91]$. Accordingly, periodontal invasive spirochetes were detected along the trigeminal nerve and in trigeminal ganglia [96]. They might also propagate along the fila olfactoria and tractus olfactorius, which would be in harmony with the olfactory hypothesis [122-124] and with previous observations showing that the olfactory tract and bulb are affected in the earliest stages of the degenerative process in AD [125].

Spirochetes attach to host cells through their surface components, including collagen-binding proteins, bacterial amyloids and pore forming proteins [126-131]. Through activation of plasminogen and factor XII, bacterial amyloids contribute to inflammation and modulate blood coagulation [132].

The innate immune system enables host cells to recognize spirochetes, execute proinflammatory defenses, and start adaptive immune responses.

Pattern recognition receptors, located on the cell membrane of various cells, particularly on phagocytes and microglia recognize unique structures of spirochetes. The largest family of pattern recognition receptors is that of Toll-like receptors (TLRs). TLRs are also present in the brain [133]. Macrophages and microglia activated through TLR signaling secrete chemokines and cytokines and express various proinflammatory molecules for the removal of pathogens and affected cells. Spirochetes and their surface lipoproteins activate TLR signaling through CD14 [134,135]. As an example, tri- or di-acylated lipoproteins of $B$. burgdorferi bind to lipopolysaccharide binding protein (LBP), which activates TLR signaling through CD14 [136].

It is noteworthy, that in addition to spirochetal antigens and DNA, D-amino acids and bacterial peptidoglycan, two natural constituents of Prokaryotic cell wall unique to bacteria, were also detected in the brain in AD
$[83,84,137,138]$. Pattern recognition receptors are upregulated in the brain in AD, and TLR2 and TLR4 gene polymorphisms influence the pathology of AD $[139,140]$. Activation of microglia with TLRs 2, 4 and 9 ligands markedly increases $A \beta$ ingestion in vitro [141]. Finally, stimulation of the immune system through TLR9 in A $\beta$ PP (Tg2576) transgenic mice results in reduction of A $\beta$ deposits [142].

Once microorganisms are recognized, the activation of the innate immune system induces phagocytosis and bacteriolysis through the formation of the membrane attack complex (MAC, C5b9) [143-145] and promotes inflammatory responses. Activation of the clotting cascade generates bradykinin, which increases vascular permeability. Spirochetes activate both the classic and alternative pathways and induce acute phase proteins. Serum amyloid A (SAA) and $C$ Reactive Protein (CRP) levels are elevated in T. pallidum and B. burgdorferi infections $[146,147]$. Through their ability to induce the production of tumor necrosis factor (TNF) by macrophages, spirochete lipoproteins play an important role in systemic and local inflammatory changes that characterize spirochetal infections [148].

In Alzheimer's disease, activated microglia that are designed to clean up bacteria and cellular debris surround senile plaques and extracellular neurofibrillary tangles [53]. Both the cellular and humoral components of the immune system reactions [48-53] and critical constituents of the classical and alternative complement pathways are associated with AD lesions [51,52,149].

Spirochetes are able to evade host defense mechanisms and establish latent and slowly progressive chronic infection. They employ a broad range of strategies to overcome antigenic recognition, phagocytosis and complement lysis. Blockade of the complement cascade allows their survival and proliferation even in immune competent hosts. Complement resistant strains of $B$. burgdorferi possess five Complement Regulatory Acquiring Surface Proteins (CRASPS), which bind to factor $\mathrm{H}(\mathrm{FH})$ and factor- $\mathrm{H}$ like protein-1 (FHL-1) of the alternative pathway $[145,150]$. Binding to the surface of spirochetes host FH and FHL-1 promotes the formation of inactive $\mathrm{iC} 3 \mathrm{~b}$ from $\mathrm{C} 3 \mathrm{~b}$ preventing MAC lysis. B. burgdorferi spirochetes possess a CD59-like complement inhibitory molecule as well [151], which by interacting with $\mathrm{C} 8$ and $\mathrm{C} 9$, inhibits binding of the opsonizing components $\mathrm{C} 4 \mathrm{~b}$ and $\mathrm{C} 3 \mathrm{~b}$ to $\mathrm{MAC}$ and consequently, prevents bacteriolysis [150]. Impaired complement lysis was also observed in T. pallidum infection [143].

B. burgdorferi protects itself from destruction by the host adaptive immune system as well. It induces interleukin-12 (IL-12), a cytokine critical for driving cellular responses toward Th1 subset [152-154]. This shift retards antibody production by Th2 cells against the spirochete. Intracellular survival of spirochetes also confers protection 
against destruction by the host defense reactions. Evasion of spirochetes will result in their survival and proliferation in the brain. Their accumulation in the cerebral cortex will lead to the formation of senile plaques, tangles and granulovacuolar-like degeneration as shown by historic observations in syphilis $[61,62]$ and by current observations and in vitro experiments reviewed here (Fig. 7).

Accumulation in the brain of "paralytic iron" is characteristic in general paresis [59]. Free iron abolishes the bactericidal effects of serum and strongly enhances bacterial virulence [155-157]. It is necessary for bacterial growth and plays a pivotal role in infection and inflammation [155-157]. Iron increases the formation of reactive oxygen intermediates causing lipid peroxidation and subsequent oxidative damage of proteins and nucleic acids [155-157]. Iron, also accumulates in the brain in AD [155,158-160].

The production of reactive oxygen and nitrogen intermediates by innate immune cells is an effective hostdefense mechanism against microbial pathogens. Activation of macrophages and other host cells by bacteria or LPS, including spirochetes and their lipoproteins generates substantial amount of nitric oxide (NO) [157], which is critical in bacterial clearance [161]. Nitric oxide also plays a central role in $\mathrm{AD}$ [162].

Chronic bacterial infections (e.g. rheumatoid arthritis, leprosy, tuberculosis, syphilis, osteomyelitis) are frequently associated with amyloid deposition. Based on previous observations we have suggested that amyloidogenic proteins might be an integral part of spirochetes and could contribute to $\mathrm{A} \beta$ deposition in $\mathrm{AD}$ [70]. Recent observations indeed showed that the $\mathrm{BH}$ (9-10) peptide of a beta-hairpin segment of B. burgdorferi outer surface protein A (OspA) forms amyloid fibrils in vitro, similar to human amyloidosis $[163,164]$. Recent observations also show that amyloid proteins constitute a previously overlooked integral part of the cellular envelope of many bacteria [163-168]. Bacterial amyloids have important biological functions and contribute to bacterial virulence and invasion of host cells $[165,166]$.

Genetic mutations occurring in AD (A $\beta$ PP, Presenilin 1 and 2) are related to the processing of $A \beta P P$ and result in increased production of $A \beta \quad 1-42$ and $A \beta$ 1-43 [169]. $A \beta P P$ revealed to be a proteoglycan core protein [170] and is involved in the regulation of immune system responses and in $\mathrm{T}$ cell differentiation [171-173]. Recent observations showed that $A \beta$ is an innate immune molecule and belongs to the family of antimicrobial peptides AMPs [174], which are involved in innate immune responses. Consequently, genetic defects in A $\beta$ PP, PS-I and PS-II should be associated with an increased susceptibility to infection. ApoE4, an important risk factor for AD, is also risk factor for infection and enhances increased expression of inflammatory mediators $[175,176]$.
Promoter polymorphisms in pro-inflammatory cytokine genes facilitate infections [177]. TNF- $\alpha$ plays a critical role in host defenses against infection $[178,179]$. The influence of TNF- $\alpha$ on T. pallidum and B. burgdorferi infections has been repeatedly reported $[153,180]$. Human Leukocyte Antigen (HLA) gene polymorphism is a dominant marker of susceptibility to infection, including B. burgdorferi infection [181]. TNF- $\alpha$ and HLA polymorphisms, which are risk factors for infection, substantially influence the risk of AD as well [182-184].

\section{Analysis of causal relationship between spirochetes and AD following Koch's and Hill's postulates}

Koch's postulates

Koch's postulates were proposed to establish causal relationship between pathogens and specific diseases [34]. Following Koch's postulates I and II, the microorganism should be isolated from the affected tissue and grown in pure culture. Regarding Koch's postulates III and IV, the cultured microorganism should cause disease when introduced into a healthy host and must be re-isolated and identified as being identical to the original causative agent.

Spirochetes were cultivated from the brains of AD patients in a modified Noguchi medium and maintained in culture for about 1 month [70]. B. burgdorferi was cultivated from the brains of 5 out of $8 \mathrm{AD}$ patients who suffered from Lyme neuroborreliosis and was maintained and propagated in pure culture $[70,85,89]$, which fulfills Koch's postulates I and II. With respect to Koch's postulates III and IV the defining pathological and biological hallmarks of AD were reproduced in vitro not only in primary mammalian neuronal and glial cell cultures but in CNS organotypic cultures as well, which aim to replace in vivo studies [107]. B. burgdorferi (strains B31, ADB1, ADB2) was also recovered in pure culture from infected cell cultures [89]. In vivo studies might bring further evidence with respect to Koch's postulates III and IV. Following Koch's postulates the causal relationship between B. burgdorferi and dementia is much stronger, than in the case of T. palli$d u m$, which is known to cause dementia, but cannot be cultivated in pure culture.

Koch himself acknowledged that the application of his postulates to establish causality is sometimes difficult and suggested that his criteria should be used as guidelines [35]. Indeed, like T. pallidum, several other bacteria and viruses cannot be grown in pure culture and based on his criteria to establish causality in chronic disorders is limited. In order to address this question, new criteria were proposed by Hill [36].

A previous review [185], on the analysis of association of infectious agent with AD following Hill's criteria concluded that the "treatment of chronic infection may become an important part of AD prevention and therapy". 
With respect to spirochetes only part of the historical and new data were included in this study.

Therefore, based on the substantial data available on the detection of spirochetes in $\mathrm{AD}$, we analyzed the probability of a causal relationship following Hill's nine criteria [36].

\section{Hill's postulates}

\section{Strength of the association}

In agreement with Honjo et al. [185], the statistical analysis shows a significant association between spirochetes and AD (Table 1).

\section{Consistency of the association}

Following Hill, the consistency of the association demands whether the results were "repeatedly observed by different persons, in different places, circumstances and times?". In 14 studies [70,80-85,90,96,98-102] spirochetes were detected in AD. Various authors in diverse laboratories, in different countries, using different techniques have detected spirochetes in AD, fulfilling Hill's claim for the consistency of association. In three studies [103-105], which failed to show the involvement of $B$. burgdorferi in $\mathrm{AD}$, evidence is lacking whether the AD patients had a positive serology for B. burgdorferi, as for this goal, the analysis of AD populations suffering from Lyme neuroborreliosis would be essential. As mentioned by Pappolla et al. [103], the possibility of the involvement of other spirochetes in AD cannot be excluded. In another study on the analysis of sero-prevalence of $B$. burgdorferi in $\mathrm{AD}$, due to the low incidence of Lyme dementia compared to AD can explain the negative result [106].

\section{Specificity of the association}

Spirochetes and spirochete specific antigens and DNA associated with lesions defining $\mathrm{AD}$ indicate the specificity of the association.

\section{Temporality of the association}

The temporal relationship of the association, is "... a question which might be particularly relevant with diseases of slow development... Have they already contracted it before?" T. pallidum infection in the atrophic form of general paresis is a historical example of temporal relationship between spirochetal infection and slowly progressive dementia $[29,63,65]$. Spirochetes were detected in AD patients with early stages of plaque-, tangle- and curly fiber-formation $[83,84]$ indicating that infection takes place long before the diagnosis of dementia is made [70].

\section{Biological gradient of the association}

That spirochetes are able to form plaque-, tangle- and curly fiber-like lesions $[70,85,107]$ and their number progressively increases in the brains of patients with mild, moderate $[83,84]$, and severe AD-type changes [70,80-87] fulfill this condition.

\section{Plausibility of the association}

T. pallidum in the atrophic form of general paresis causes dementia, brain atrophy and $\mathrm{A} \beta$ deposition similar to the pathological and biological hallmarks of $\mathrm{AD}$ $[61,62,67,85]$. That AD-type pathological changes were also induced in vitro by B. burgdorferi and were observed in the brains of patients with concurrent $A D$ and Lyme neuroborreliosis indicate that chronic spirochetal infection can cause dementia.

\section{Coherence of the association}

As proposed by Hill, the cause-and-effect interpretation of the data should not seriously conflict with the generally known facts of the natural history and biology of the disease [36]. That a slow acting unconventional infectious agent acquired at an early age and requiring decades to become active may be involved in $\mathrm{AD}$ was never discarded [186,187]. Fischer, Alzheimer and their colleagues discussed the possibility that microorganisms may play a role in the formation of senile plaques and described similarities in the clinical and/or pathological manifestations of Alzheimer disease and general paresis $[32,33,58,59,67,86]$. Chronic spirochetal infection can cause slowly progressive dementia, cortical atrophy, chronic inflammation and $A \beta$ deposition, which are indistinguishable from those occurring in $\mathrm{AD}[29,61,62,67,85,86]$. Spirochete-host interactions result in various immune responses, free radicals, apoptosis and amyloid deposition, which are typical of AD [86]. The genetic defects occurring in AD can facilitate infection as well [for a review see 86]. Spirochetal infections cause cerebral hypoperfusion [188-190], cerebrovascular lesions and severely disturbed cortical capillary network $[29,191,192]$, which are also important factors in the pathogenesis of AD [193-199]. As in AD, mixed forms of dementia due to cortical atrophy and vascular lesions frequently occur in neurospirochetoses [29,63], further strengthening the coherence of the association. All these observations indicate that, the association is in harmony with the natural history and biology of AD.

\section{Experimental evidences}

Following exposure of primary mammalian neuronal and glial cells and brain organotypic cultures to spirochetes, lesions similar to the defining pathological and biological hallmarks of AD were produced [107] representing experimental evidence in favor of a causal relationship between $\mathrm{AD}$ and spirochetes. These experimental data $[107,89]$ indicate that as observed in syphilis $[29,61,62]$ and Lyme neuroborreliosis $[85,89]$, the evasion of spirochetes can result in their survival and proliferation and the production of lesions similar to senile plaques, tangles and granulovacuolar-degenerations (Figure 3). Additional experimental data include transmission of $A \beta$ amyloidosis to experimental animals [200-203], the observations showing the immune regulatory function of APP [171-173], the antimicrobial properties of $A \beta$ [174] 


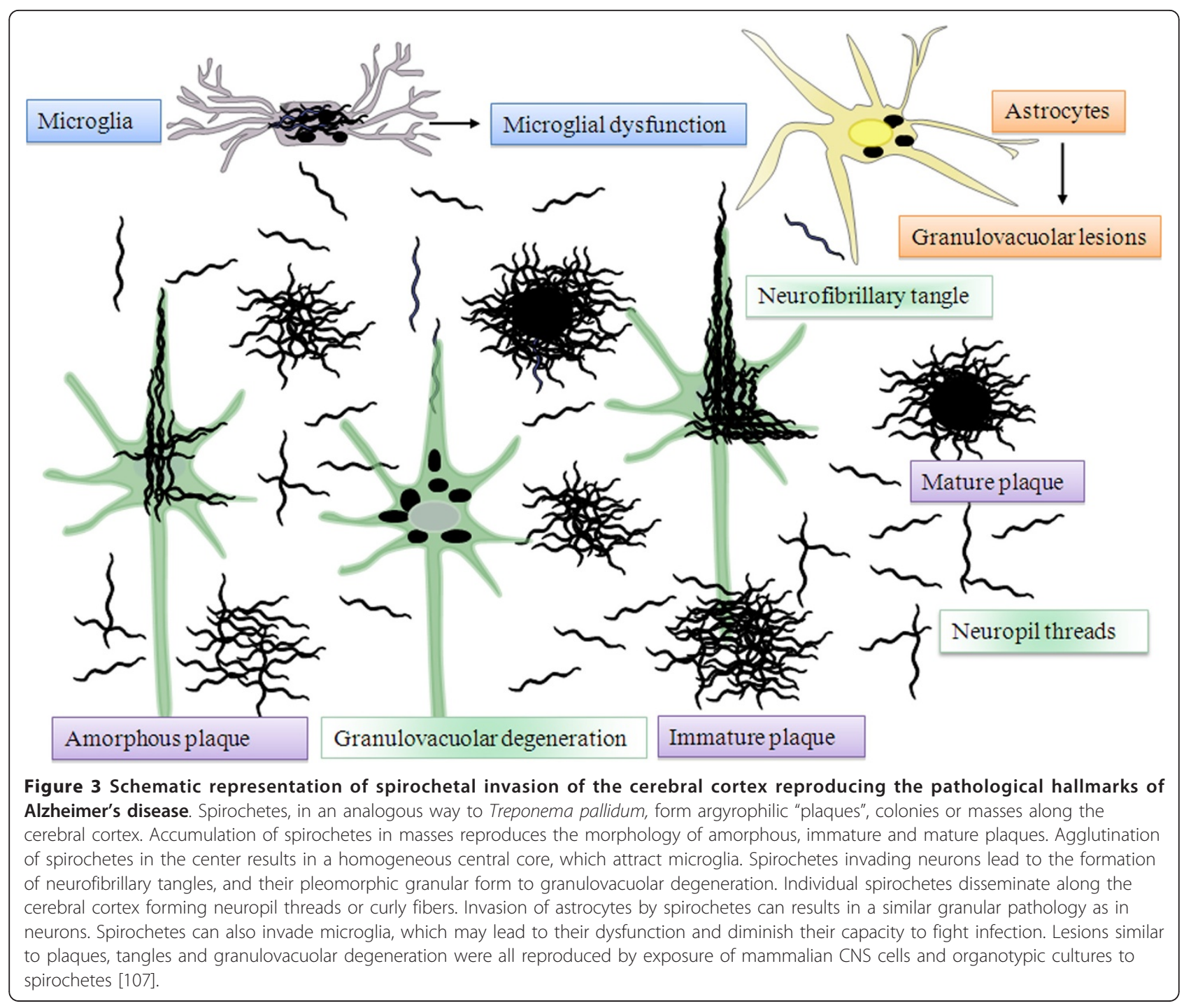

and the improvement in symptoms of AD patients following antibiotic treatment [204-208]. Further research and clinical trials would be primordial.

\section{Analogy of the association}

The analogy of clinical and pathological hallmarks of $\mathrm{AD}$ to those of the atrophic form of general paresis and Lyme neuroborreliosis as revealed by historic observations and based on retrospective studies meets this condition $[29,33,61,62,67,85,86]$.

Taken together, the analysis of historic and recent data available in the literature following Koch's and Hill's criteria is in favor of a causal relationship between neurospirochetosis and $\mathrm{AD}$.

\section{Conclusions}

Various types of spirochetes, including B. burgdorferi, and six periodontal pathogen spirochetes ( $T$. socranskii, T. pectinovorum, T. denticola, T. medium, T. amylovorum and $T$. maltophilum) were detected in the brains of $\mathrm{AD}$ patients. The pathological and biological hallmarks of $\mathrm{AD}$, including increased $\mathrm{A} \beta \mathrm{PP}$ level, $\mathrm{A} \beta$ deposition and tau phosphorylation were induced by spirochetes in vitro. The statistical analysis showed a significant association between spirochetes and AD. The strongly significant association, the high risk factor and the analysis of data following Koch's and Hill's criteria, are indicative of a causal relationship between neurospirochetoses and AD.

Spirochetes are able to escape destruction by the host immune reactions and establish chronic infection and sustained inflammation. In vivo studies with long exposure times will be necessary to efficiently study the sequence of events and the cellular mechanisms involved in spirochete induced $\mathrm{AD}$-type host reactions and $\mathrm{A} \beta$-plaque, "tangle" and "granulovacuolar" formation. The characterization of all types of spirochetes and co-infecting bacteria and viruses is needed, in order to develop serological tests for 
the early detection of infection. The pathological process is thought to begin long before the diagnosis of dementia is made therefore, an appropriate targeted treatment should start early in order to prevent dementia.

Persisting spirochetal infection and their persisting toxic components can initiate and sustain chronic inflammatory processes through the activation of the innate and adaptive immune system involving various signaling pathways. In the affected brain the pathogens and their toxic components can be observed, along with host immunological responses. The response itself is characteristic of chronic inflammatory processes associated with the site of tissue damage. The outcome of infection is determined by the genetic predisposition of the patient, by the virulence and biology of the infecting agent and by various environmental factors, such as exercise, stress and nutrition.

The accumulated knowledge, the various views, and hypotheses proposed to explain the pathogenesis of $\mathrm{AD}$ form together a comprehensive entity when observed in the light of a persisting chronic inflammation and amyloid deposition initiated and sustained by chronic spirochetal infection. As suggested by Hill, once the probability of a causal relationship is established prompt action is needed. Similarly to syphilis, one may prevent and eradicate dementia in AD. The impact on healthcare costs and on the suffering of the patients would be substantial.

\section{Acknowledgements}

I am grateful for many colleagues and friends, from so many countries, who supported during decades this new emerging field of Alzheimer's research. I would like to express my gratitude to Edith and Pat McGeer and Kamel Khalili for their encouragement, for the productive work done together and for the pleasant years I have spent in their laboratories in Canada and in the U.S.A. I will always be grateful for the unconditional help and support received from Pushpa Darekar and Sheng Yu in the laboratory work. I am also obliged to Rudolf Kraftsik who has always been a loyal colleague and friend who always helped me with neuroimaging and statistical analyses. He also contributed to the statistical analysis of the present review. The work was supported by the Prevention Alzheimer International Foundation, Switzerland.

\section{Authors' contributions}

$J M$ wrote the manuscript and approved the final version of the manuscript.

\section{Competing interests}

The author declares that they have no competing interests.

Received: 16 May 2011 Accepted: 4 August 2011

Published: 4 August 2011

\section{References}

1. Marshall BJ, Warren JR: Unidentified curved bacilli in the stomach of patients with gastritis and peptic ulceration. Lancet 1984, 1:1311-1315.

2. Laitinen K, Laurila A, Pyhälä L, Leinonen M, Saikku P: Chlamydia pneumonia infection induces inflammatory changes in the aortas of rabbits. Infect Immun 1997, 65:4832-4835.

3. Saikku P: Epidemiology of Chlamydia pneumoniae in atherosclerosis. Am Heart J 1999, S138:500-503.

4. Mendall MA, Goggin PM, Molineaux N, Levy J, Toosy T, Strachan D, Camm AJ, Northfield TC: Relation of Helicobacter pylori infection and coronary heart disease. Br Heart J 1994, 71:437-439.
5. Martîn-de-Argila C, Boixeda D, Cantón R, Gisbert JP, Fuertes A: High seroprevalence of Helicobacter pylori infection in coronary heart disease. Lancet 1995, 346:310.

6. Renvert S, Pettersson T, Ohlsson O, Persson GR: Bacterial profile and burden of periodontal infection in subjects with a diagnosis of acute coronary syndrome. J Periodontol 2006, 77:1110-1119.

7. Zaremba M, Górska R, Suwalski P, Kowalski J: Evaluation of the Incidence of Periodontitis-Associated Bacteria in the Atherosclerotic Plaque of Coronary Blood Vessels. J Periodontol 2007, 78:322-327.

8. Chiu B: Multiple infections in carotid atherosclerotic plaques. Am Heart J 1999, 138:S534-536.

9. Haraszthy VI, Zambon JJ, Trevisan M, Zeid M, Genco RJ: Identification of periodontal pathogens in atheromatous plaques. J Periodontol 2000, 71:1554-1560.

10. Rassu M, Cazzavillan S, Scagnelli M, Peron A, Bevilacqua PA, Facco M, Bertoloni G, Lauro FM, Zambello R, Bonoldi E: Demonstration of Chlamydia pneumoniae in atherosclerotic arteries from various vascular regions. Atherosclerosis 2001, 158:73-79.

11. Toplak $H$, Haller EM, Lauermann T, Weber K, Bahadori B, Reisinger EC, Tilz GP, Wascher TC: Increased prevalence of IgA-Chlamydia antibodies in NIDDM patients. Diabetes Res Clin Pract 1996, 32:97-101.

12. Kozák R, Juhász E, Horvát G, Harcsa E, Lövei L, Sike R, Szele K: Helicobacter pylori infection in diabetic patients. Orv Hetil 1999, 140:993-995.

13. Quatrini M, Boarino V, Ghidoni A, Baldassarri AR, Bianchi PA, Bardella MT: Helicobacter pylori prevalence in patients with diabetes and its relationship to dyspeptic symptoms. J Clin Gastroenterol 2001, 32:215-217.

14. Gulcelik NE, Kaya E, Demirbas B, Culha C, Koc G, Ozkaya M, Cakal E, Serter R, Aral Y: Helicobacter pylori prevalence in diabetic patients and its relationship with dyspepsia and autonomic neuropathy. J Endocrinol Invest 2005, 28:214-217.

15. Hughes MK, Fusillo MH, Roberson BS: Positive fluorescent treponemal antibody reactions in diabetes. Appl Microbiol 1970, 19:425-428.

16. Miklossy J, Martins RN, Darbinian N, Khalili K, McGeer PL: Type 2 Diabetes: Local Inflammation and Direct Effect of Bacterial Toxic Components. Open Pathol J 2006, 2:86-95.

17. Martin RJ: Infections and asthma. Clin Chest Med 2006, 27:87-98.

18. MacDowell AL, Bacharier LB: Infectious triggers of asthma. Immunol Allergy Clin North Am 2005, 25:45-66.

19. Micillo E, Bianco A, D'Auria D, Mazzarella G, Abbate GF: Respiratory infections and asthma. Allergy 2000, Suppl 61:42-45.

20. Teig N, Anders A, Schmidt C, Rieger C, Gatermann S: Chlamydophila pneumoniae and Mycoplasma pneumoniae in respiratory specimens of children with chronic lung diseases. Thorax 2005, 60:962-966.

21. Goldman CG, Mitchell HM: Helicobacter spp. other than Helicobacter pylori. Helicobacter 2010, 15(Suppl 1):69-75.

22. Vermeire $S$, Van Assche G, Rutgeerts P: Inflammatory bowel disease and colitis? new concepts from the bench and the clinic. Curr Opin Gastroenterol 2011, 27:32-37.

23. Navaneethan U, Giannella RA: Infectious colitis. Curr Opin Gastroenterol, 2011, 27:66-71.

24. Hasan N, Pollack A, Cho I: Infectious causes of colorectal cancer. Infect Dis Clin North Am 2010, 4:1019-1039.

25. Lalande JD, Behr MA: Mycobacteria in Crohn's disease: how innate immune deficiency may result in chronic inflammation. Expert Rev Clin Immunol 2010, 6:633-641.

26. Marttila RJ, Arstila P, Nikoskelainen J, Halonen PE, Rinne UK: Viral antibodies in the sera from patients with Parkinson disease. Eur Neurol 1977, 15:25-33.

27. Rott R, Herzog S, Fleischer B, Winokur A, Amsterdam J, Dyson W, Koprowski H: Detection of serum antibodies to Borna disease virus in patients with psychiatric disorders. Science 1985, 228:755-756.

28. Beaman BL: Bacteria and neurodegeneration. In Neurodegenerative Diseases Edited by: Caino DWB, Saunders, Orlando, FL 1994, 319-338,

29. Miklossy J: Biology and neuropathology of dementia in syphilis and Lyme disease. In Dementias. Edited by: Duyckaerts C, Litvan I. Edinburgh, London, New York, Oxford, Philadelphia, St-Louis, Toronto, Sydney: Elsevier; 2008:825-844, Series Editor Aminoff MJ, Boller F, Schwab DS: Handbook of Clinical Neurology vol. 89.

30. Salvatore M, Morzunov S, Schwemmle M, Lipkin WI: Borna disease virus in brains of North American and European people with schizophrenia and bipolar disorder. Lancet 1997, 349:1813-1814. 
31. Langford D, Masliah E: The emerging role of infectious pathogens in neurodegenerative diseases. Exp Neurol 2003, 184:553-555.

32. Fischer O: Miliare Nekrosen mit drusigen Wucherungen der Neurofibrillen, eine regelmässige Veränderung der Hirnrinde bei seniler Demenz. Monatschr f Psychiat Neurol 1907, 22:361-372.

33. Alzheimer A: Über eigenartige Krankheitsfälle des späteren Alters. Z Ges Neurol Psychiat 1911, 4:356-385

34. Koch R: Die Aetiologie der Tuberculose. Mitt Kaiser Gesundh 1884, 2:1-88.

35. Koch R: Ueber den augenblicklichen Stand der bakteriologischen Cholera Diagnose. J Hyg Inf 1893, 14:319-333.

36. Hill AB: The environment and disease: Association or causation? Proceedings of the Royal Society of Medicine, Section of Occupational Medicine, Meeting January 1965, 14:295-300.

37. Alzheimer A: Über eine eigenartige Erkrankung der Hirnrinde. Allg Z Psychiat Med 1907, 64:146-148.

38. Katzman R: The prevalence and malignancy of Alzheimer's disease: a major killer. Arch Neurol 1976, 33:217-218.

39. Terry RD, Davies P: Dementia of the Alzheimer type. Ann Rev Neurosci 1980, 3:77-95

40. Bertram L, Tanzi RE: The genetic epidemiology of neurodegenerative disease. J Clin Invest 2005, 115:1449-1457.

41. Nagy Z: The last neuronal division: a unifying hypothesis for the pathogenesis of Alzheimer's disease. J Cell Mol Med 2005, 9:531-541.

42. Tanzi RE, Vaula G, Romano DM, Mortilla M, Huang TL, Tupler RG, Wasco W, Hyman BT, Haines $J \mathrm{~L}$, Jenkins $B J$, et al: Assessment of amyloid betaprotein precursor gene mutations in a large set of familial and sporadic Alzheimer disease cases. Am J Hum Genet 1992, 51:273-282.

43. Roses AD: Apolipoprotein $E$ is a relevant susceptibility gene that affects the rate of expression of Alzheimer's disease. Neurobiol Aging 1994, 2(Suppl):165-167.

44. McGeer PL, McGeer EG: Polymorphisms in inflammatory genes and the risk of Alzheimer disease. Arch Neurol 2001, 58:1790-1792.

45. Bertram L, McQueen MB, Mullin K, Blacker D, Tanzi RE: Systematic metaanalyses of Alzheimer disease genetic association studies: the AlzGene database. Nat Genet 2007, 39:17-23

46. Guo JP, Arai T, Miklossy J, McGeer PL: Abeta and tau form soluble complexes that may promote self aggregation of both into the insoluble forms observed in Alzheimer disease. Proc Natl Acad Sci USA 2006, 103:1953-1938.

47. Perry G, Richey PL, Siedlak SL, Smith MA, Mulvihill P, DeWitt DA, Barnett J, Greenberg BD, Kalaria RN: Immunocytochemical evidence that the betaprotein precursor is an integral component of neurofibrillary tangles of Alzheimer's disease. Am J Pathol 1993, 143:1586-1593.

48. McGeer PL, Itagaki S, Tago H, McGeer EG: Reactive microglia in patients with senile dementia of the Alzheimer type are positive for the histocompatibility glycoprotein HLA-DR. Neurosci Lett 1987, 79:195-200.

49. Griffin WS, Stanley LC, Ling C, White L, MacLeod V, Perrot L, White CL, Araoz C: Brain interleukin 1 and S-100 immunoreactivity are elevated in Down syndrome and Alzheimer disease. Proc Natl Acad Sci USA 1989, 86:7611-7615

50. McGeer PL, Rogers J: Anti-inflammatory agents as a therapeutic approach to Alzheimer's disease. Neurology 1992, 42:447-449.

51. Schwab C, McGeer PL: Inflammatory aspects of Alzheimer disease and other neurodegenerative disorders. J Alzheimers Dis 2008, 13:359-369.

52. McGeer PL, McGeer EG: The inflammatory response system of brain: Implications for therapy of Alzheimer and other neurodegenerative diseases. Brain Res Rev 1995, 21:195-218.

53. McGeer PL, McGeer EG: Local neuroinflammation and the progression of Alzheimer's disease. J Neurovirol 2002, 8:529-538.

54. Webster S, Lue LF, Brachova L, Tenner AJ, McGeer PL, Terai K, Walker DG, Bradt B, Cooper NR, Rogers J: Molecular and cellular characterization of the membrane attack complex, C5b-9, in Alzheimer's disease. Neurobiol Aging 1997, 18:415-421.

55. Stewart WF, Kawas C, Corrada M, Metter EJ: Risk of Alzheimer's disease and duration of NSAID use. Neurology 1997, 48:626-632.

56. Anthony JC, Breitner JC, Zandi PP, Meyer MR, Jurasova I, Norton MC Stone SV: Reduced incidence of AD with NSAID but not $\mathrm{H} 2$ receptor antagonists: The Cache County Study. Neurology 2000, 59:880-886.

57. in't Veld BA, Launer LJ, Hoes AW, Ott A, Hofman A, Breteler MM, Stricker BH: NSAIDs and incident Alzheimer's disease. The Rotterdam Study. Neurobiol Aging 1998, 19:607-611.
58. Hübner AH: Zur Histopathologie der senilen Hirnrinde. Arch Psychiat Neurol 1908, 46:598-609.

59. Perusini G: Histology and clinical findings of some psychiatric diseases of older people. In (Perusini G. Histologische und hispopathologische Arbeiten. Volume 3. Edited by: Nissl F, Alzheimer A. Gustav Fischer, Jena; 1910:297-351, In The early story of Alzheimer's disease. Translation of the historic papers by Alois Alzheimer, Oskar Fischer, Francesco Bonfiglio, Emil Kraepelin, Gaetano Perusini. Edited by Bick K, Amaducci L, Pepeu G. Padova, Liviana press: 1987: 82-128.

60. Noguchi H, Moore JW: A demonstration of Treponema pallidum in the brain of general paralysis cases. J Exp Med 1913, 17:232-238.

61. Pacheco e Silva AC: Espirochetose dos centros nervos. Memorias do hospicio de Juquery, anno III-IV 1926, 3-4:1-27.

62. Pacheco e Silva AC: Localisation du Treponema Pallidum dans le cerveau des paralytiques généraux. Rev Neurol 1926, 2:558-565.

63. Merritt HH, Adams RD, Solomon HC: Neurosyphilis Oxford University Press, London; 1946.

64. Bonfiglio F: Di speciali reperti in un caso di probabile sifilide cerebrale. Riv Speriment Fren 1908, 34:196-206.

65. Vinken PJ, Bruyn GW: Handbook of Neurology. Amsterdam, New York: Elsevier; 197833.

66. Volland W: Die Kolloide Degeneration des Gehirns bei progressiver Paralyse in ihrer Beziehung zur lokalen Amyloidose. Dtsch Path Gesellsch 1938, 31:515-520.

67. Miklossy J, Rosemberg S, McGeer PL: Beta amyloid deposition in the atrophic form of general paresis. In Alzheimer's Disease: New advances. Proceedings of the 10th International Congress on Alzheimer's Disease (ICAD). Edited by: Iqbal K, Winblad B, Avila J. Medimond, International Proceedings; 2006:429-433.

68. MacDonald AB: Borrelia in the brains of patients dying with dementia. JAMA 1986, 256:2195-2196.

69. Dupuis MJ: Multiple neurologic manifestations of Borrelia burgdorferi infection. Rev Neurol 1988, 144:765-775.

70. Miklossy J: Alzheimer's disease - A spirochetosis? Neuroreport 1993, 4:841-848.

71. Schaeffer S, Le Doze F, De la Sayette V, Bertran F, Viader F: Dementia in Lyme disease. Presse Med 1994, 123:861.

72. Fallon BA, Nields JA: Lyme disease: a neuropsychiatric illness. Am J Psychiatry 1994, 151:1571-1583.

73. Pennekamp A, Jaques M: Chronic neuroborreliosis with gait ataxia and cognitive disorders. Praxis 1997, 86:867-869.

74. Southern P, Sanford J: Relapsing fever: a clinical and microbiological review. Medicine 1969, 48:129-149.

75. Thein M, Bunikis I, Denker K, Larsson C, Cutler S, Drancourt M, Schwan TG, Mentele R, Lottspeich F, Bergström S, Benz R: : Oms38 is the first identified pore-forming protein in the outer membrane of relapsing fever spirochetes. J Bacteriol 2008, 190:7035-7042.

76. Paster BJ, Dewhirst FE: Phylogenetic foundation of spirochetes. J Mol Microbiol Biotechnol 2000, 2:341-344.

77. Dewhirst FE, Tamer MA, Ericson RE, Lau CN, Levanos VA, Boches SK, Galvin JL, Paster BJ: The diversity of periodontal spirochetes by $16 \mathrm{~S}$ rRNA analysis. Oral Microbiol Immunol 2000, 15:196-202.

78. Mikosza AS, La T, de Boer WB, Hampson DJ: Comparative prevalences of Brachyspira aalborgi and Brachyspira (Serpulina) pilosicoli as etiologic agents of histologically identified intestinal spirochetosis in Australia. $J$ Clin Microbiol 2001, 39:347-350.

79. Trott DJ, Jensen NS, Saint Girons I, Oxberry SL, Stanton TB, Lindquist D, Hampson DJ: Identification and characterization of Serpulina pilosicoli isolates recovered from the blood of critically ill patients. J Clin Microbiol 1997, 35:482-485.

80. Miklossy J, Kasas S, Janzer RC, Ardizzoni F, Van der Loos H: Further morphological evidence for a spirochetal etiology of Alzheimer's Disease. NeuroReport 1994, 5:1201-1204.

81. Miklossy J: The spirochetal etiology of Alzheimer's disease: A putative therapeutic approach. In Alzheimer Disease: Therapeutic Strategies. Proceedings of the Third International Springfield Alzheimer Symposium. Edited by: Giacobini E, Becker R. Birkhauser Boston Inc.; 1994:, Part I: 41-48.

82. Miklossy J, Gern L, Darekar P, Janzer RC, Van der, Loos H: Senile plaques, neurofibrillary tangles and neuropil threads contain DNA? I Spirochetal and Tick-borne Dis (JSTD) 1995, 2:1-5. 
83. Miklossy J, Darekar P, Gern L, Janzer RC, Bosman FT: Bacterial peptidoglycan in neuritic plaques in Alzheimer's disease. Azheimer's Res 1996, 2:95-100

84. Miklossy J: Chronic inflammation and amyloidogenesis in Alzheimer's disease: Putative role of bacterial peptidoglycan, a potent inflammatory and amyloidogenic factor. Alzheimer's Rev 1998, 3:45-51.

85. Miklossy J, Khalili K, Gern L, Ericson RL, Darekar P, Bolle L, Hurlimann J, Paster BJ: Borrelia burgdorferi persists in the brain in chronic Lyme neuroborreliosis and may be associated with Alzheimer disease. $J$ Alzheimer's Dis 2004, 6:1-11.

86. Miklossy J: Chronic inflammation and amyloidogenesis in Alzheimer's disease - role of spirochetes. J Alzheimer's Dis 2008, 13:381-391.

87. Hesse L, Bostock J, Dementin S, Blanot D, Mengin-Lecreulx D, Chopra I: Functional and biochemical analysis of Chlamydia trachomatis MurC, an enzyme displaying UDP-N-acetylmuramate:amino acid ligase activity. J Bacteriol 2003, 185:6507-6512

88. McCoy AJ, Adams NE, Hudson AO, Gilvarg C, Leustek T, Maurelli AT: L,Ldiaminopimelate aminotransferase, a trans-kingdom enzyme shared by Chlamydia and plants for synthesis of diaminopimelate/lysine. Proc Nat/ Acad Sci USA 2006, 103:17909-17914.

89. Miklossy J, Kasas S, Zurn AD, McCall S, Yu S, McGeer PL: Persisting atypical and cystic forms of Borrelia burgdorferi and local inflammation in Lyme neuroborreliosis. J Neuroinflammation 2008, 5:40.

90. McLaughlin R, Kin NM, Chen MF, Nair NP, Chan EC: Alzheimer's disease may not be a spirochetosis. Neuroreport 1999, 10:1489-1491.

91. Gastinel P: Précis de bactériologie médicale. Collections de récis médicaux Masson and Cie, Paris; 1949.

92. Jacquet $L$, Sézary $A$ : Des formes atypiques et dégénératives du tréponéme pâle. Bull mem Soc Med Hop Par 1907, 24:114.

93. Mattman LH: Cell wall deficient forms: stealth pathogens. CRC Press, Inc, Boca Raton, Fla.: 21993

94. Chan EC, Klitorinos A, Gharbia S, Caudry SD, Rahal MD, Siboo R: Characterization of a $4.2-\mathrm{kb}$ plasmid isolated from periodontopathic spirochetes. Oral Microbiol Immunol 1996, 11:365-368.

95. Riviere GR, Weisz KS, Adams DF, Thomas DD: Pathogen-related oral spirochetes from dental plaque are invasive. Infect Immun 1991, 59:3377-3380.

96. Riviere GR, Riviere KH, Smith KS: Molecular and immunological evidence of oral Treponema in the human brain and their association with Alzheimer's disease. Oral Microbiol Immunol 2002, 17:113-118.

97. Kamer AR, Dasanayake AP, Craig RG, Glodzik-Sobanska L, Bry M, de Leon MJ: Alzheimer's disease and peripheral infections: the possible contribution from periodontal infections, model and hypothesis. J Alz Dis 2008, 13:437-449.

98. MacDonald AB, Miranda JM: Concurrent neocortical borreliosis and Alzheimer's disease. Hum Pathol 1987, 18:759-761.

99. MacDonald AB: Concurrent neocortical borreliosis and Alzheimer's Disease. Ann N Y Acad Sci 1988, 539:468-470.

100. Meer-Scherrer L, Chang Loa C, Adelson ME, Mordechai E, Lobrinus JA, Fallon BA, Tilton RC: Lyme disease associated with Alzheimer's disease. Curr Microbiol 2006, 52:330-332.

101. MacDonald AB: Transfection "Junk" DNA - A link to the pathogenesis of Alzheimer's disease? Med Hypotheses 2006, 66:1140-1141.

102. MacDonald AB: Plaques of Alzheimer's disease originate from cysts of Borrelia burgdorferi, the Lyme disease spirochete. Med Hypotheses 2006, 67:592-600.

103. Pappolla MA, Omar R, Saran B, Andorn A, Suarez M, Pavia C, Weinstein A, Shank D, Davis K, Burgdorfer W: Concurrent neuroborreliosis and Alzheimer's disease: analysis of the evidence. Hum Pathol 1989, 20:753-757.

104. Gutacker M, Valsangiacomo C, Balmelli T, Bernasconi MV, Bouras C, Piffaretti JC: Arguments against the involvement of Borrelia burgdorferi sensu lato in Alzheimer's disease. Res Microbiol 1998, 149:31-35.

105. Marques AR, Weir SC, Fahle GA, Fischer SH: Lack of evidence of Borrelia involvement in Alzheimer's disease. J Infect Dis 2000, 182:1006-1007.

106. Galbussera A, Tremolizzo L, Isella V, Gelosa G, Vezzo R, Vigorè L, Brenna M, Ferrarese C, Appollonio I: Lack of evidence for Borrelia burgdorferi seropositivity in Alzheimer disease. Alzheimer Dis Assoc Disord 2008, 22:308.

107. Miklossy J, Kis A, Radenovic A, Miller L, Forro L, Martins R, Reiss K, Darbinian N, Darekar P, Mihaly L, Khalili K: Beta-amyloid deposition and
Alzheimer's type changes induced by Borrelia spirochetes. Neurobiol Aging 2006, 27:228-236.

108. Nicolson GL: Chronic Bacterial and Viral Infections in Neurodegenerative and Neurobehavioral Diseases. Lab Med 2008, 39:291-299.

109. Reiber H, Lange P: Quantification of Virus-Specific Antibodies in Cerebrospinal Fluid and Serum: Sensitive and Specific Detection of Antibody Synthesis in Brain. Clin Chem 1991, 37:1153-1160.

110. Furuta $Y$, Kawabata H, Ohtani F, Watanabe H: Western blot analysis for diagnosis of Lyme disease in acute facial palsy. Laryngoscope 2001, 111:719-723.

111. Gylfe A, Wahlgren M, Fahlén L, Bergström S: Activation of latent Lyme borreliosis concurrent with a herpes simplex virus type 1 infection. Scand J Infect Dis 2002, 34:922-924.

112. Mantovani E, Costa IP, Gauditano G, Bonoldi VL, Higuchi ML, Yoshinari NH: Description of Lyme disease-like syndrome in Brazil. Is it a new tick borne disease or Lyme disease variation? Braz J Med Biol Res 2007, 40:443-456.

113. Balin BJ, Gérard HC, Arking EJ, Appelt DM, Branigan PJ, Abrams JT, Whittum-Hudson JA, Hudson AP: Identification and localization of Chlamydia pneumoniae in the Alzheimer's brain. Med Microbiol Immunol 1998, 187:23-42

114. Balin BJ, Little CS, Hammond CJ, Appelt DM, Whittum-Hudson JA, Gérard HC, Hudson AP: Chlamydophila pneumoniae and the etiology of late-onset Alzheimer's disease. J Alzheimers Dis 2008, 13:371-380.

115. Jamieson GA, Maitland NJ, Wilcock GK, Craske J, Itzhaki RF: Latent herpes simplex virus type 1 in normal and Alzheimer's disease brains. J Med Virol 1991, 33:224-227.

116. Itzhaki RF, Wozniak MA: Herpes simplex virus type 1 in Alzheimer's disease: the enemy within. J Alzheimers Dis 2008, 13:393-405.

117. Martîn-de-Argila C, Boixeda D, Cantón R, Gisbert JP, Fuertes A: High seroprevalence of Helicobacter pylori infection in coronary heart disease. Lancet 1995, 346:310.

118. Yoon JW, Jun HS: Viruses cause type 1 diabetes in animals. Ann NY Acad Sci 2006, 1079:138-146.

119. Papamichael KX, Papaioannou G, Karga H, Roussos A, Mantzaris GJ: Helicobacter pylori infection and endocrine disorders: is there a link? World J Gastroenterol 2009, 15:2701-2707.

120. Inaba H, Amano A: Roles of Oral Bacteria in Cardiovascular Diseases From Molecular Mechanisms to Clinical Cases: Implication of Periodontal Diseases in Development of Systemic Diseases. J Pharmacol Sci 2010, 113:103-109.

121. Kamer AR, Craig RG, Dasanayake AP, Brys M, Glodzik-Sobanska L, de Leon MJ: Inflammation and Alzheimer's disease: possible role of periodontal diseases. Alzheimers Dement 2008, 4:242-250.

122. Averback P: Two new lesions in Alzheimer's disease. Lancet 1983, 2:1203.

123. Mann DM, Tucker CM, Yates PO: Alzheimer's disease: an olfactory connection? Mech Aging Develop 1988, 42:1-15.

124. Hardy JA, Mann DM, Wester P, Winblad B: An integrative hypothesis concerning the pathogenesis and progression of Alzheimer's disease. Neurobiol Aging 1986, 7:489-502.

125. Christen-Zaech S, Kraftsik R, Pillevuit O, Kiraly M, Martins R, Khalili K, Miklossy J: Early olfactory involvement in Alzheimer's disease. Can J Neurol Sci 2003, 30:20-25

126. Umemoto T, Li M, Namikawa I: Adherence of human oral spirochetes by collagen-binding proteins. Microbiol Immunol 1997, 41:917-923.

127. Skare JT, Mirzabekov TA, Shang ES, Blanco DR, Erdjument-Bromage $H$, Bunikis J, Bergström S, Tempst P, Kagan BL, Miller JN, Lovett MA: The Oms66 (p66) protein is a Borrelia burgdorferi porin. Infect Immun 1997, 65:3654-3661.

128. Cluss RG, Silverman DA, Stafford TR: Extracellular secretion of the Borrelia burgdorferi Oms28 porin and Bgp, a glycosaminoglycan binding protein. Infect Immun 2004, 72:6279-6286.

129. Bárcena-Uribarri I, Thein M, Sacher A, Bunikis I, Bonde M, Bergström S, Benz R: P66 porins are present in both Lyme disease and relapsing fever spirochetes: a comparison of the biophysical properties of $\mathrm{P} 66$ porins from six Borrelia species. Biochim Biophys Acta 2010, 1798:1197-1203.

130. Brissette CA, Rossmann E, Bowman A, Cooley AE, Riley SP, Hunfeld KP Bechtel M, Kraiczy P, Stevenson B: The borrelial fibronectin-binding protein RevA is an early antigen of human Lyme disease. Clin Vaccine Immunol 2010, 17:274-280.

131. Coburn J, Cugini C: Targeted mutation of the outer membrane protein P66 disrupts attachment of the Lyme disease agent, Borrelia 
burgdorferi, to integrin alphavbeta3. Proc Natl Acad Sci USA 2003, 100:7301-7306

132. Gebbink MF, Claessen D, Bouma B, Dijkhuizen L, Wösten HA: Amyloids-a functional coat for microorganisms. Nat Rev Microbiol 2005, 3:333-341.

133. Crack PJ, Bray PJ: Toll-like receptors in the brain and their potential roles in neuropathology. Immunol Cell Biol 2007, 85:476-480.

134. Bulut Y, Faure E, Thomas L, Equils O, Arditi M: Cooperation of Toll-like receptor 2 and 6 for cellular activation by soluble tuberculosis factor and Borrelia burgdorferi outer surface protein A lipoprotein: role of Tollinteracting protein and IL-1 receptor signaling molecules in Toll-like receptor 2 signaling. J Immunol 2001, 167:987-994.

135. Sellati TJ, Bouis DA, Kitchens RL, Darveau RP, Pugin J, Ulevitch RJ, Gangloff SC, Goyert SM, Norgard MV, Radolf JD: Treponema pallidum and Borrelia burgdorferi lipoproteins and synthetic lipopeptides activate monocytic cells via a CD14-dependent pathway distinct from that used by lipopolysaccharide. J Immunol 1998, 160:5455-5464.

136. Schröder NW, Heine H, Alexander C, Manukyan M, Eckert J, Hamann L, Göbel UB, Schumann RR: Lipopolysaccharide binding protein binds to triacylated and diacylated lipopeptides and mediates innate immune responses. J Immunol 2004, 173:2683-2691.

137. Fisher GH, D'Aniello A, Vetere A, Padula L, Cusano GP, Man EH: Free Daspartate and D-alanine in normal and Alzheimer brain. Brain Res Bull 1991, 26:983-985.

138. D'Aniello A, Vetere A, Fisher GH, Cusano G, Chavez M, Petrucelli L: Presence of D-alanine in proteins of normal and Alzheimer human brain. Brain Res 1992, 592:44-48.

139. Minoretti P, Gazzaruso C, Vito CD, Emanuele E, Bianchi M, Coen E, Reino M, Geroldi D: Effect of the functional toll-like receptor 4 Asp299Gly polymorphism on susceptibility to late-onset Alzheimer's disease. Neurosci Lett 2006, 391:147-149.

140. Balistreri CR, Grimaldi MP, Chiappelli M, Licastro F, Castiglia L, Listì F, Vasto S, Lio D, Caruso C, Candore G: Association between the polymorphisms of TLR4 and CD14 genes and Alzheimer's disease. Curr Pharm Des 2008, 14:2672-2677.

141. Tahara K, Kim HD, Jin JJ, Maxwell JA, Li L, Fukuchi K: Role of toll-like receptor signalling in Abeta uptake and clearance. Brain 2006, 129:3006-3019

142. Scholtzova H, Kascsak RJ, Bates KA, Boutajangout A, Kerr DJ, Meeker HC, Mehta PD, Spinner DS, Wisniewski T: Induction of toll-like receptor 9 signaling as a method for ameliorating Alzheimer's disease-related pathology. J Neurosci 2009, 29:1846-1854.

143. Blanco DR, Champion CI, Lewinski MA, Shang ES, Simkins SG, Miller JN, Lovett MA: Immunization with Treponema pallidum outer membrane vesicles induces high-titer complement-dependent treponemicidal activity and aggregation of T. pallidum rare outer membrane proteins (TROMPs). J Immunol 1999, 163:2741-2746.

144. Lawrenz MB, Wooten RM, Zachary JF, Drouin SM, Weis JJ, Wetsel RA, Norris SJ: Effect of complement component C3 deficiency on experimental Lyme borreliosis in mice. Infect Immun 2003, 71:4432-4440.

145. Kraiczy P, Skerka C, Kirschfink M, Zipfel PF, Brade V: Mechanism of complement resistance of pathogenic Borrelia burgdorferi isolates. Int Immunopharmacol 2001, 1:393-401.

146. Ray A, Kumar D, Shakya A, Brown CR, Cook JL, Ray BK: Serum amyloid Aactivating factor-1 (SAF-1) transgenic mice are prone to develop a severe form of inflammation-induced arthritis. J Immunol 2004, 173:4684-4691.

147. Berlit P: Clinical and laboratory findings with giant cell arteritis. J Neurol Sci 1992, 111:1-12

148. Marangoni A, Aldini R, Sambri V, Giacani L, Di Leo K, Cevenini R: Production of tumor necrosis factor alpha by Treponema pallidum, Borrelia burgdorferi s.l., and Leptospira interrogans in isolated rat Kupffer cells. FEMS Immunol Med Microbiol 2004, 40:187-191.

149. McGeer PL, McGeer E, Rogers J, Sibley J: Anti-inflammatory drugs and Alzheimer disease. Lancet 1990, 335:1037.

150. Kraiczy P, Würzner R: Complement escape of human pathogenic bacteria by acquisition of complement regulators. Mol Immunol 2006, 43:31-44.

151. Pausa $M$, Pellis V, Cinco M, Giulianini $P G$, Presani $G$, Perticarari $S$, Murgia $R$, Tedesco F: Serum-resistant strains of Borrelia burgdorferi evade complement-mediated killing by expressing a CD59-like complement inhibitory molecule. J Immunol 2003, 170:3214-3222.
152. Radolf JD, Robinson EJ, Bourell KW, Akins DR, Porcella SF, Weigel LM, Jones JD, Norgard MV: Characterization of outer membranes isolated from Borrelia burgdorferi, the Lyme disease spirochete. Infect Immun 1995, 63:2154-2163.

153. Rasley A, Anguita J, Marriott I: Borrelia burgdorferi induces inflammatory mediator production by murine microglia. I Neuroimmunol 2002, 130:22-31.

154. Ramesh G, Alvarez AL, Roberts ED, Dennis VA, Lasater BL, Alvarez X, Philipp MT: Pathogenesis of Lyme neuroborreliosis: Borrelia burgdorferi lipoproteins induce both proliferation and apoptosis in rhesus monkey astrocytes. Eur J Immunol 2003, 33:2539-2550.

155. Weinberg G, Miklossy J: Iron and infection. J Alzheimer's Dis 2008 13:451-463.

156. Griffiths E: Iron and bacterial virulence - a brief overview. Biol Met 1991, 4:7-13.

157. Weinberg ED: Iron depletion: a defense against intracellular infection and neoplasia. Life Sci 1992, 50:1289-1297.

158. Goodman L: Alzheimer's disease; a clinico-pathologic analysis of twentythree cases with a theory on pathogenesis. J Nerv Ment Dis 1953, 118:97-130.

159. Bishop GM, Robinson SR, Liu Q, Perry G, Atwood CS, Smith MA: Iron: a pathological mediator of Alzheimer disease? Dev Neurosci 2002, 24:184-187.

160. Miller LM, Wang Q, Telivala TP, Smith RJ, Lanzirotti A, Miklossy J: Synchrotron-based infrared and X-ray imaging shows focalized accumulation of $\mathrm{Cu}$ and $\mathrm{Zn}$ co-localized with beta-amyloid deposits in Alzheimer's disease. J Struct Biol 2006, 155:30-37.

161. Lirk P, Hoffmann G, Rieder J: Inducible nitric oxide synthase-time for reappraisal. Curr Drug Targets Inflamm Allergy 2002, 1:89-108.

162. Bogdan C: Nitric oxide and the immune response. Nat Immunol 2001, 2:907-916.

163. Ohnishi S, Koide A, Koide SJ: Solution conformation and amyloid-like fibril formation of a polar peptide derived from a b-hairpin in the OspA single-layer b-sheet. Mol Biol 2000, 301:477-489.

164. Ohnishi S, Koide A, Koide S: The roles of turn formation and cross-strand interactions in fibrillization of peptides derived from the OspA singlelayer beta-sheet. Protein Sci 2001, 10:2083-2092.

165. Chapman MR, Robinson LS, Pinkner JS, Roth R, Heuser J, Hammar M, Normark S, Hultgren SJ: : Role of Escherichia coli curli operons in directing amyloid fiber formation. Science 2002, 295:851-855.

166. Otzen D, Nielsen PH: We find them here, we find them there: functional bacterial amyloid. Cell Mol Life Sci 2008, 65:910-927.

167. Larsen P, Nielsen JL, Dueholm MS, Wetzel R, Otzen D, Nielsen PH: Amyloid adhesins are abundant in natural biofilms. Environ Microbiol 2007, 9:3077-3090.

168. Jordal PB, Dueholm MS, Larsen P, Petersen SV, Enghild JJ, Christiansen G, Højrup P, Nielsen PH, Otzen DE: Widespread abundance of functional bacterial amyloid in Mycolata and other Gram-positive bacteria. Appl Environ Microbiol 2009, 75:4101-4110.

169. Hardy J: The Alzheimer family of diseases: many etiologies, one pathogenesis? Proc Natl Acad Sci USA 1997, 94:2095-2097.

170. Schubert D, Schroeder R, LaCorbiere M, Saitoh T, Cole G: Amyloid beta protein precursor is possibly a heparan sulfate proteoglycan core protein. Science 1998, 241:1759-1763.

171. Allen JS, Murphy GM Jr, Eng LF, Stultz KE, Davies HD, Pickford LB, Tinklenberg JR: Alzheimer's disease: beta-amyloid precursor protein mRNA expression in mononuclear blood cells. Neurosci Lett 1991, 132:109-112.

172. Mönning U, König G, Prior R, Mechler H, Schreiter-Gasser U, Masters CL, Beyreuther K: Synthesis and secretion of Alzheimer amyloid beta A4 precursor protein by stimulated human peripheral blood leucocytes. FEBS Lett 1990, 277:261-266.

173. Ledoux S, Rebai N, Dagenais A, Shaw IT, Nalbantoglu J, Sekaly RP, Cashman NR: Amyloid precursor protein in peripheral mononuclear cells is up-regulated with cell activation. J Immunol 1993, 150:5566-5575.

174. Soscia SJ, Kirby JE, Washicosky KJ, Tucker SM, Ingelsson M, Hyman B, Burton MA, Goldstein LE, Duong S, Tanzi RE, Moir RD: The Alzheimer's disease-associated amyloid beta-protein is an antimicrobial peptide. PLoS One 2010, 5:e9505. 
175. Urosevic N, Martins RN: Infection and Alzheimer's disease: the APOE epsilon4 connection and lipid metabolism. J Alzheimers Dis 2008, 13:421-435.

176. Licastro F, Porcellini E, Caruso C, Lio D, Corder EH: Genetic risk profiles for Alzheimer's disease: integration of APOE genotype and variants that upregulate inflammation. Neurobiol Aging 2007, 28:1637-1643.

177. Knight JC, Kwiatkowski D: Inherited variability of tumor necrosis factor production and susceptibility to infectious disease. Proc Assoc Am Physicians 1999, 111:290-298.

178. Shaw MA, Donaldson IJ, Collins A, Peacock CS, Lins-Lainson Z, Shaw JJ, Ramos F, Silveira F, Blackwell JM: Association and linkage of leprosy phenotypes with HLA class II and tumour necrosis factor genes. Genes Immun 2001, 2:196-204.

179. Sigal LH: Lyme disease: a review of aspects of its immunology and immunopathogenesis. Annu Rev Immunol 1997, 15:63-92.

180. Marangoni A, Aldini R, Sambri V, Giacani L, Di Leo K, Cevenini R: Production of tumor necrosis factor alpha by Treponema pallidum, Borrelia burgdorferi s.l., and Leptospira interrogans in isolated rat Kupffer cells. FEMS Immunol Med Microbiol 2004, 40:187-191.

181. Steere AC, Dwyer E, Winchester R: Association of chronic Lyme arthritis with HLA-DR4 and HLA-DR2 alleles. N Engl J Med 1990, 323:219-223.

182. Collins JS, Perry RT, Watson B Jr, Harrell LE, Acton RT, Blacker D, Albert MS, Tanzi RE, Bassett SS, McInnis MG, Campbell RD, Go RC: Association of a haplotype for tumor necrosis factor in siblings with late-onset Alzheimer disease: the NIMH Alzheimer Disease Genetics Initiative. Am J Med Genet 2000, 96:823-830.

183. McCusker SM, Curran MD, Dynan KB, McCullagh CD, Urquhart DD, Middleton D, Patterson CC, Mcllroy SP, Passmore AP: Association between polymorphism in regulatory region of gene encoding tumour necrosis factor alpha and risk of Alzheimer's disease and vascular dementia: a case-control study. Lancet 2001, 357:436-439.

184. Gnjec A, D'Costa K, Laws SM, Hedley R, Balakrishnan K, Taddei K, Martins G, Paton A, Verdile G, Gandy SE, Broe GA, Brooks WS, Bennett H, Piguet O, Price P, Miklossy J, Hallmayer J, McGeer PL, Martins RN: Association of alleles carried at TNFA -850 and BAT1 -22 with Alzheimer's disease. $J$ Neuroinflammation 2008, 5:36.

185. Honjo K, van Reekum R, Verhoeff NP: Alzheimer's disease and infection: do infectious agents contribute to progression of Alzheimer's disease? Alzheimers Dement 2009, 5:348-360.

186. Wisniewsky HM: Possible viral etiology of neurofibrillary changes and neuritic plaques. In Alzheimer's Disease: Senile Dementia and Related Disorders (Aging, Vol 7). Edited by: Katzman R, Terry RD, Bick KL. Raven Press, New York, NA; 1978:555-557.

187. Khachaturian ZS: Diagnosis of Alzheimer's disease. Arch Neurol 1985, 42:1097-1105.

188. Rosenbaum M, Roseman E, Aring CD, Ferris EB Jr: Intracranial blood flow in dementia paralytica, cerebral atrophy and schizophrenia. Arch Neurol Psychiat 1942, 47:793.

189. Sumiya H, Kobayashi K, Mizukoshi C, Aoki T, Koshino Y, Taki J, Tonami N: Brain perfusion SPECT in Lyme neuroborreliosis.? J Nucl Med. 1997, 38:1120-1122

190. Logigian EL, Johnson KA, Kijewski MF, Kaplan RF, Becker JA, Jones KJ, Garada BM, Holman BL, Steere AC: Reversible cerebral hypoperfusion in Lyme encephalopathy. Neurology 1997, 49:1661-1670.

191. Patterson JL Jr, Heyman A, Nichols FT Jr: Cerebral blood flow and oxygen consumption in neurosyphilis. J Clin Invest 1950, 10:1327-1334.

192. Miklossy J, Kuntzer T, Bogousslavsky J, Regli F, Janzer RC: Meningovascular form of neuroborreliosis: similarities between neuropathological findings in a case of Lyme disease and those occurring in tertiary neurosyphilis. Acta Neuropathol 1990, 80:568-572.

193. Hachinski V, Munoz DG: Cerebrovascular pathology in Alzheimer's disease: cause, effect or epiphenomenon? Ann N Y Acad Sci 1997, 26:1-6.

194. Johnson K, Mueller S, Walshe T, English R, Holman B: Cerebral perfusion imaging in Alzheimer's disease. Arch Neurol 1987, 44:165-168.

195. de la Torre JC: Impaired cerebromicrovascular perfusion. Summary of evidence in support of its causality in Alzheimer's disease. Ann N Y Acad Sci 2000, 924:136-152

196. Esiri MM, Nagy Z, Smith MZ, Barnetson L, Smith AD: Cerebrovascular disease and threshold for dementia in the early stage of Alzheimer's disease. Lancet 1999, 354:919-920.
197. Kalaria RN: The role of cerebral ischemia in Alzheimer's disease. Neurobiol Aging 2000, 21:321-330

198. Miklossy J: Cerebral hypoperfusion induces cortical watershed microinfarcts which may further aggravate cognitive decline in Alzheimer's disease. Neurol Res 2003, 25:605-610.

199. Suter OC, Sunthorn T, Kraftsik R, Straubel J, Darekar P, Khalili K, Miklossy J: Cerebral hypoperfusion generates cortical watershed microinfarcts in Alzheimer disease. Stroke 2002, 33:1986-1992.

200. Baker HF, Ridley RM, Duchen LW, Crow TJ, Bruton CJ: Evidence for the experimental transmission of cerebral beta-amyloidosis to primates. Int $J$ Exp Pathol 1993, 74:441-454.

201. Baker HF, Ridley RM, Duchen LW, Crow TJ, Bruton CJ: Experimental induction of beta-amyloid plaques and cerebral angiopathy in primates. Ann N Y Acad Sci 1993, 695:228-231.

202. Baker HF, Ridley RM, Duchen LW, Crow TJ, Bruton CJ: Induction of beta (A4)-amyloid in primates by injection of Alzheimer's disease brain homogenate. Comparison with transmission of spongiform encephalopathy. Mol Neurobiol 1994, 8:25-39.

203. Ridley RM, Baker HF, Windle CP, Cummings RM: Very long term studies of the seeding of beta-amyloidosis in primates. J Neural Transm 2006, 113:1243-1251.

204. Kornhuber HH: Propionibacterium acnes in the cortex of patients with Alzheimer's disease. Eur Arch Psychiatry Clin Neurosci 1996, 246:108-109.

205. Kornhuber HH: Reply on critical comments on Propionibacterium acnes in the cortex of patients with Alzheimer's disease. Eur Arch Psychiatry Clin Neurosci 1996, 246:226

206. Loeb MB, Molloy DW, Smieja M, Standish T, Goldsmith CH, Mahony J, Smith S, Borrie M, Decoteau E, Davidson W, McDougall A, Gnarpe J, O'DONNell M, Chernesky M: A randomized, controlled trial of doxycycline and rifampin for patients with Alzheimer's disease. J Am Geriatr Soc 2004, 52:381-387.

207. Tsai GE, Falk WE, Gunther J, Coyle JT: Improved cognition in Alzheimer's disease with short-term D-cycloserine treatment. Am J Psychiatry 1999, 156:467-469.

208. Kim HS, Suh YH: Minocycline and neurodegenerative diseases. Behav Brain Res 2009, 196:168-179.

\section{doi:10.1186/1742-2094-8-90}

Cite this article as: Miklossy: Alzheimer's disease - a neurospirochetosis. Analysis of the evidence following Koch's and Hill's criteria. Journal of Neuroinflammation 2011 8:90

\section{Submit your next manuscript to BioMed Central and take full advantage of:}

- Convenient online submission

- Thorough peer review

- No space constraints or color figure charges

- Immediate publication on acceptance

- Inclusion in PubMed, CAS, Scopus and Google Scholar

- Research which is freely available for redistribution

Submit your manuscript at www.biomedcentral.com/submit
C Biomed Central 